Faculdade de Economia, Contabilidade e Ciência da Informação e Documentação - FACE Curso: Especialização em Gestão Universitária

Trabalho de Conclusão de Curso (monografia)

Assédio moral: consequências na saúde física e psicológica do servidor da UnB

\title{
ASSÉDIO MORAL:
}

consequências na saúde física e psicológica do servidor da UnB 
Ivanise Oliveira de Brito

\section{Curso de Gestão Universitária}

\section{ASSÉDIO MORAL:}

consequências na saúde física e psicológica do servidor da UnB

Projeto de monografia apresentado ao Departamento de Administração da Faculdade de Economia, Contabilidade e Ciência da Informação e Documentação - FACE da UnB - UnB, como requisito parcial para obtenção do grau de Especialista em Gestão Universitária.

Orientadora: Professora Dra. Marisa Cardoso Trindade 


\section{Uma poesia}

ASSÉDIO MORAL

Mário, o chefe,

Assediador moral inveterado

Assediava Mauro, almoxarife,

Reiterada vezes...

Como um xerife

À moda antiga

Misantropo assumido

Humilhava-o com cautela

Ou de forma agressiva...

Mauro, o almoxarife,

Por meses a fio

Tolerou, sofreu, chorou...

Por fim adoeceu...

Cedeu, sem forças,

Ao cerco implacável...

Hoje é suicida...

Agora, Melo, o malandro,

Assedia o Mário

Na cadeia

De forma habitual...

Mário, ex-chefe,

Tolera, sofre, chora...

Ora a Deus arrependido...

Se arrependimento matasse!!! 
Curso de Especialização em Gestão Universitária - Aluna: Ivanise Oliveira de Brito

BANCA EXAMINADORA

Profa. Dra. Marisa Cardoso Trindade Orientadora

Prof. Dr. César Agusto Tiburcio Membro da Banca Examinadora 
Curso de Especialização em Gestão Universitária - Aluna: Ivanise Oliveira de Brito

Agradeço ao meu Deus pela oportunidade. 
Curso de Especialização em Gestão Universitária - Aluna: Ivanise Oliveira de Brito

Ofereço a todos aqueles que direta e indiretamente contribuíram para a realização desse trabalho. 


\section{SIGLAS}

Associação Brasileira de Normas Técnicas (ABNT)

Código Civil Brasileiro (CCB)

Código Penal Brasileiro (CPB)

Centro Brasileiro de Estudos de Saúde (CEBES)

Centro de Referência em Saúde do Trabalhador Regional de Ribeirão Preto (CEREST)

Faculda de Economia, Contabilidade e Ciência da Informação e Documentação (FACE)

Doenças Osteomusculares Relacionadas (DORT)

Escola Nacional de Saúde Publica (ENSP)

Lesões por Esforços Repetitivos (LER)

Organização das Nações Unidas (ONU)

Organização Internacional do Trabalho (OIT)

Organização Mundial de Saúde (OMS)

Secretaria de Recursos Humanos (SRH) 


\section{FIGURAS}

Figura 1. Distribuição dos 100\% dos respondentes entre SIM e NÃO 49

Figura 1a. Distribuição dos 30,56\% dos respondentes entre os períodos apontados em que ocorreu o fato 50

Figura 2. Distribuição dos 66,67\% dos respondentes em cada sexo 51

Figura 3. Distribuição dos respondentes nos tipos de relações com o agressor 52

Figura 4. Distribuição dos 77,78\% dos respondentes em SIM e NÃO 53

Figura 4a. Distribuição dos 61,11\% dos respondentes de SIM no tipo de dano sofrido 54

Figura 5. Distribuição dos 97,22\% dos respondentes entre os quem tem (SIM) e os que NÃO tem algum tipo de doença 55

Figura 6. Distribuição dos 94,44\% que responderam SIM e NÃO 56

Figura 7. Distribuição dos 94,44\% dos respondentes entre Professores, T. Administrativos e Outros 57

Figura 8. Distribuição dos 94,44\% dos respondentes quanto ao tipo de educação 58

Figura 9. Distribuição dos $100 \%$ dos respondentes entre o sexo feminino e o masculino _ 59 Figura 10. Distribuição dos 94\% dos respondentes entre as faixas etárias 60

Figura 11. Dos 72,22\% que se declararam assediados na questão $\mathrm{n}^{\circ} .1$-> 52,78\% relataram o fato; $19,44 \%$ não relataram 61 


\section{SUMÁRIO}

\section{INTRODUÇÃO}

2 O QUE É ASSÉDIO MORAL

3 ASSÉDIO MORAL E A VIOLÊNCIA FÍSICA E PSICOLÓGICA__ 18

3.1 Assédio moral: espécies, tipos de agressores e estratégias dos assediadores__ 19

3.2 Consequências do assédio moral __ 27

3.3 A legislação, aspectos jurídicos e éticos para proteção contra o assédio _ـ 29

4 METODOLOGIA_ 37

5 RELATOS ESPONTÂNEOS DE CASOS DE ASSÉDIO MORAL COLETADOS NA PESQUISA — 38

5.1 Caso 1- Usurpação do trabalho, da criação e da competência do subordinado __ 38

5.2 Caso 2 - Assédio sexual de chefe (mulher) contra subordinado (homem) __ 40

5.3 Caso 3 - Servidora é afastada do setor de lotação sem explicação ___ 41

5.4 Caso 4 - Servidora que adquiriu LER no trabalho é ridicularizada pela chefe___ 42

5.5 Caso 5 - O Chefe imputava à sua auxiliar imediata os danos que ele mesmo causava _ 43

Caso 6 - Servidora que se achava "a maior pensadora do mundo" tenta desqualificar demais colegas no ambiente de trabalho __ 44

5.6 Caso 7 - Servidor constrangido moralmente não pode processar o agressor em razão do medo de represálias contra as testemunhas

5.7 Caso 8 - Servidora, sem motivo justificado, foi impedida de ter acesso aos documentos necessários ao seu trabalho _ 45

5.8 Caso 9 - Estagiário é removido do setor de trabalho sem motivo justo ___ 45

5.9 Caso 10 - Servidora sofre por perseguição religiosa___ 46

5.10 Caso 11 - Servidora sofre difamações dinates dos colegas __ 46

5.11 Caso 12 - Servidora sofre exclusão __ 47

5.12 Caso 13 - Servidora sofria constantes constragimentos__ 47

5.13 Caso 14 - Servidora sofria constantes humilhações e discrimações___ 47

6 ANÁLISE DAS RESPOSTAS 49

7 CONCLUSÃO E RECOMENDAÇÕES __ 62

REFERENCIAS_ 64

SITES CONSULTADOS_ 66

APÊNDICES__ 67

Apêndice A - Questionário aplicado na pesquisa __ 67

Apêndice B - Codificação da tabulação __ 69

Apêndice C - Tabulação das respostas__ 70

Anexo A 71

CONTATO COM A AUTORA 


\title{
ASSÉDIO MORAL: consequências na saúde física e psicóloga do servido da UnB MORAL HARASSMENT:
}

\author{
consequences for the physical health and psychologist of served the University
} Ivanise Oliveira de Brito

\section{RESUMO}

$\mathrm{O}$ assédio moral pode ocorrer tanto na esfera familiar quanto no meio profissional-organizacional. $\mathrm{O}$ foco do tema analisado será o assédio moral consequências na saúde física e psicológica do servidor da Universidade de Brasília.

Assim, buscando contribuir para uma avaliação desse tipo de comportamento abusivo, este trabalho apresenta resultados significativos em forma de gráficos e relatos de servidores que dizem terem sofridos assédio moral no ambiente de trabalho da UnB.

Os resultados mostram que os danos sofridos por agressões são diversos e que está interferindo nas relações interpessoais e no ambiente laboral.

A pesquisa foi realizada com 36 pessoas, com questionários com dez perguntas, sendo uma solicitação para um relato de caso de assédio moral. A distribuição foi feira pela própria autora no Campus da UnB, no período de 23 de março a 18 de abril de 2010. Dos questionários distribuídos, cem por cento foram respondidos e atenderam à proposta em relatar casos de assédio moral por eles sofridos, 52,78\% dos respondentes. Portanto, mais da metade relataram que foram ou estão sendo vítimas de assédio moral na UnB. A análise identificou que os danos foram diversos porém $52,78 \%$ sofreram dano psicológico.

A pesquisa mostra que grande parte dos servidores desconhecem qualquer tipo de divulgação proveniente da Instituição sobre o que é assédio moral. No final desse trabalho são feitas sugestões para um melhor esclarecimento de sobre o que é assédio e como se proteger para não se transformar em vítimas dos assediadores.

\section{PALAVRAS CHAVES: - ASSÉDIO MORAL, SAÚDE, DANOS, TRABALHO}

\begin{abstract}
Bullying can occur both in the family sphere as in professional and organizational environment. The analysis will focus theme bullying effects on physical and psychological health of the server of the University of Brasilia. So, seeking to contribute to an evaluation of this type of abusive behaviour, this work presents significant results in the form of graphs and reports servers who say they have suffered psychological harassment in the workplace of UnB. the results show that the damages suffered by assaults are different and that is interfering in interpersonal relations and in the workplace. The survey was conducted with 36 people, with questionnaires with ten questions, being a request to a case report of harassment. The distribution was fair by the author on the campus of UnB, during the period from 23 March to 18 April 2010. Of the questionnaires distributed, 100 per cent have been answered and meet proposed to report cases of moral harassment suffered by them, $52.78 \%$ of respondents. Therefore, more than half reported that have been or are being victims of mobbing in UnB. The analysis identified that the damages were mixed but $52.78 \%$ suffered psychological damage. Research shows that most servers are unaware of any kind arising from the imposition of disclosure about what is bullying. At the end of this work are made suggestions for a better clarification on what constitutes harassment and how to protect yourself to not become victims of harassers.
\end{abstract}

KEY WORDS: MORAL HARASSMENT, STRESS, HEALTH. 


\section{INTRODUÇÃO}

Há muito se discute sobre casos de assédio moral sofrido por servidores no ambiente de trabalho da Universidade de Brasília. O conhecimento desses fatos serviu de motivação para o empreendimento de uma pesquisa sobre o tema, e avaliar quão disseminado está o fenômeno no ambiente de trabalho. O assédio moral, notório pelos seus efeitos danosos contra a saúde física e psicológica das pessoas, pode estar causando prejuízos a uma ampla gama de pessoas: aos servidores, suas famílias e amigos, a Instituição, e assim a própria sociedade.

Logo, julgou-se ser urgente focar a pesquisa na existência ou não desse fenômeno que interfere nas relações interpessoais dentro do espaço de trabalho da UnB, uma vez que nessa Instituição, atualmente, conforme informação da homepage <http://www.unb.br>, acessada em 17 de maio 2010, trabalham mais de 1.900 professores e cerca de 2.525 outros servidores, distribuídos em ambientes de trabalho espalhados em: cinco decanatos, vinte e cinco instituto e faculdades, sessenta departamentos, uma assessoria, seis secretarias, vinte e nove centros, e órgãos complementares tais como o Hospital Universitário de Brasília, o Hospital Veterinário, a Biblioteca Central, a Fazenda Água Limpa, o Centro de Informática, a UnB TV e a Editora UnB, além de dez órgãos diversos e quatro campis.

Com esse estudo não se pretende responder a todos os problemas relacionados a comportamentos abusivos dentro do ambiente de trabalho da UnB. Mas espera-se que, com a realização dele e com o resultado dos dados levantados, se possa ter informações consistentes sobre a existência de assédio moral nas relações de trabalho dessa Instituição.

Conforme mencionado acima, os prejuízos causados pelo assédio moral afetam não somente o indivíduo, mas o coletivo, a instituição e a sociedade como um todo. E, para que esse fenômeno seja minimizado, é preciso conhecê-lo para saber identificá-lo. Assim todos os servidores deverão ter conhecimento de suas características, independentemente de sexo, grau de conhecimento intelectual ou da categoria de trabalho a que pertençam.

Dessa forma, espera-se que os resultados dessa pesquisa contribuam para que se estabeleça uma política de prevenção sobre o assédio moral na UnB, incentivando compor- 
tamentos positivos, pautados na moral que a nossa sociedade aprova, na ética e no profissionalismo, impedindo, assim, a banalização desse mal.

O trabalho aqui discutido será apresentado em forma de monografia para o Curso de Gestão Universitária do Departamento de Administração da Faculdade de Economia, Contabilidade e Ciência da Informação e Documentação - (FACE).

O objetivo geral deste trabalho foi identificar, por meio de pesquisa, se existe a prática de assédio moral no ambiente de trabalho do servidor da UnB e quais as consequências para a saúde física e psicológica das pessoas. E a partir deste explicitou-se os objetivos específicos:

- Conceituar assédio moral;

- Comprovar se existe a prática de assédio moral no ambiente de trabalho do servidor da UnB;

- Verificar se o assédio moral teve consequências na saúde física e psicológica do servidor;

- Destacar que gênero assedia mais no ambiente de trabalho;

- Entregar os resultados da pesquisa à SRH/UnB como contribuição para desenvolvimento de uma política de esclarecimento e formação de uma consciência coletiva de combate a todas as manifestações de assédio moral.

Com a sociedade industrial moderna, verifica-se que o fenômeno assédio moral vem acontecendo corriqueiramente em diversas instituições. Onde há homem, mulher, chefe, subordinado, superior, inferior etc., esse fenômeno invariavelmente surge. A UnB não está imune a esse problema, conforme já mencionado na introdução.

Esse trabalho, então, tem a intenção de verificar se a prática do assédio moral existe dentro do cenário de trabalho da UnB e quais são as consequências na saúde física e psicológica do servidor. Também tem a pretensão de fornecer os resultados da pesquisa à SRH/UnB para o desenvolvimento de uma política de esclarecimento e formação de uma consciência coletiva de combate a todas as manifestações de assédio moral, nas diferentes relações de trabalho, visando a prevenção de problemas de saúde, financeiros e judiciais. 


\section{O QUE É ASSÉDIO MORAL}

Começando pelo dicionário Houaiss ${ }^{1}$, a palavra assédio significa “insistência impertinência, perseguição, sugestão ou pretensão constantes em relação a alguém.” E para a enciclopédia livre Wikipédia a definição de assédio moral voltada para os trabalhadores é: "assédio moral é a exposição dos trabalhadores e trabalhadoras a situações humilhantes e constrangedoras, repetitivas e prolongadas durante a jornada de trabalho e no exercício de suas funções.”

Por sua vez, moral é definida por Fernandes et al (1993, p. 487) como:

Moral é a parte da filosofia que trata dos costumes ou dos deveres do homem para com seus semelhantes e para consigo e o conjunto de nossas faculdades morais; tudo o que diz respeito à inteligência ou ao espírito, por oposição ao que é material: Que é conforme aos bons costumes; referente ou favorável aos bons costumes; referente ou favorável aos costumes; relativo ao domínio espiritual.”

Assim, assédio moral para Hirigoyen (2002), apud Barreto (2006) numa perspectiva dos trabalhadores significa:

"toda e qualquer conduta abusiva manifestando-se, sobretudo por comportamentos, palavras, atos, gestos, escritos, que possam trazer dano à personalidade, à dignidade ou à integridade física ou psíquica de uma pessoa, pondo em perigo seu emprego ou degradando o ambiente de trabalho. [...] consistente na exposição dos trabalhadores a situações humilhantes e constrangedoras, repetitivas e duradouras durante a jornada laboral, [...]."

Outro conceito muito empregado é o de Freitas et al (2008, p. 37):

"O assédio moral é uma conduta abusiva, intencional, frequente e repetida, que ocorre no ambiente de trabalho e que visa diminuir, humilhar, vexar, constranger, desqualificar e demolir psiquicamente um individuo ou um grupo, degradando as suas condições de

\footnotetext{
1 Houaiss Eletrônico. Versão monousuário 3.0 - Junho de 2009. Copyright @2001-2009 Instituto Antônio Houaiss. Produzido e distribuído por Editora Objetiva Ltda.

2< http://pt.wikipedia.org/wiki/Ass\%C3\%A9dio_moral > Acessado em 20 de maio de 2010.
} 
trabalho, atingindo sua dignidade e colocando em risco a sua integridade pessoal e profissional".

Essas condições abusivas e repetitivas no ambiente de trabalho deixam o indivíduo num estado de angústia e desolação que, fatalmente, o levará a uma situação de doenças psicológicas.

Para o sueco Heinz Leymann, psicólogo do trabalho (1990, p. 120) assédio

moral é:

“A deliberada degradação das condições de trabalho através do estabelecimento de comunicações não éticas (abusivas), que se caracterizam pela repetição, por longo tempo, de um comportamento hostil de um superior ou colega (s) contra um indivíduo que apresenta, como reação de um quadro de miséria física, psicológica e social duradoura."

O termo assédio moral foi adotado oficialmente no Brasil com o projeto de lei3 sobre assédio moral discutido na Câmara Municipal de São Paulo. Porém o tema assédio moral recebeu uma maior divulgação quando a doutora Margarida Barreto, médica do trabalho elaborou a sua tese de mestrado com o título de "Uma Jornada de Humilhações", concluída no ano 2000. Ela ouviu 2.072 pessoas, das quais $42 \%$ declararam ter sofrido repetitivas humilhações no trabalho. A propagação do tema se intensificou com a publicação do livro da psicanalista francesa Marie-France Hirigoyen, Assédio moral: a violência perversa do cotidiano, em 1998 na França, e lançado no Brasil em maio de 2002.

O assédio moral é um fenômeno que atinge todas as esferas da sociedade em diversos países do mundo. Esse mal que afeta a saúde física e psicológica do indivíduo gera os mais diversos transtornos no ambiente de trabalho ou em outro qualquer ambiente. As suas características são as formas contínuas de tratamento desumano com as pessoas. Geralmente são relações desrespeitosas, sem observância da ética, de longa duração, de uma ou mais pessoas agindo contra uma ou mais pessoas. Normalmente, o(s) assediador(es) visa(m) a desesta-

\footnotetext{
3 Aguiar (2006) ainda esclarece que o termo assédio moral é a nomenclatura adotada no Brasil e surge, oficialmente no campo do direito administrativo municipal em 28 de agosto de 1999, por meio de projeto de lei número 425/1999 de autoria do vereador Arselinno Tatto, apresentado na câmara municipal de São Paulo e transformado em lei municipal de número 13.228 (10 de janeiro de 2002), dispõe sobre a aplicação das penalidades a prática desse comportamento entre o uncionalismo da administração pública municipal direta. < http://www.cesumar.br/epcc2009/anais/rafaela_caroline_schon.pdf>
} 
bilização física e/ou psicológica daquele(s) escolhido(s) como vítima(s), no seu ambiente de trabalho ou em qualquer ambiente de relação humana duradora.

De qualquer forma, para efeito deste estudo, o assédio moral será visto com foco nas relações de trabalho. Nesse ambiente, muitas vezes o assediador visa desestabilizar os trabalhadores, em especial as mulheres grávidas, os homossexuais, os negros, bem como, também, os possuidores de limites físicos e aqueles que são portadores de algum tipo de doença crônica, além de outras, pois essa relação é exemplificativa.

Por isso, há na doutrina sócio-psicológica várias definições sobre o que é assédio moral. Todas elas falam dos prejuízos que ele acarreta na saúde física e psicológica do ser humano. Considerando o ambiente de trabalho, em seu livro Assédio moral: a violência do cotidiano, Hirigoyen (2002, p. 65), afirma ser o assédio moral é:

“... toda e qualquer conduta abusiva manifestando-se sobretudo por comportamentos, palavras, atos, gestos, escritos que possam trazer danos à personalidade, à dignidade, ou à integridade física ou psíquica de uma pessoa, pôr em perigo o seu emprego ou degradar o ambiente de trabalho."

Prosseguindo, a mesma escritora, fundamentada em sólida pesquisa que fizera, declara que essa conduta abusiva "é um processo real de destruição moral, que pode levar à doença mental ou ao suicídio.” Hirigoyen (2002, p.16). Essa definição é a mais pertinente no momento para este trabalho. No decorrer do desenvolvimento, outros ângulos do assédio moral serão expostos, porém a definição aqui adotada permanecerá válida.

O assédio moral no ambiente de trabalho, entre superiores e subordinados ou entre colegas de igual hierarquia acarreta graves consequências à saúde física e psicológica do servidor, além de gerar prejuízos à instituição, à sociedade e ao próprio Estado. Existe um custo social (médico/financeiro/paz social) na recuperação do indivíduo que sofre ou sofreu assédio moral. É importante lembrar que esse custo é repartido por toda a sociedade. Do ponto de vista individual, além da saúde debilitada (física e psicológica), há o custo financeiro para o qual o indivíduo nem sempre está preparado. 
Por outro, o Estado (a sociedade) também é onerado financeiramente, gastando recursos que poderiam ser melhor empregados.

A sociedade também perde porque é violada a dignidade da pessoa humana direito fundamental garantido na Constituição. Direito esse que, sem a devida proteção, dá espaço para a violação do estado de direito, com prejuízos para toda a sociedade civil.

$\mathrm{O}$ assédio moral além de afetar a saúde física/financeiro do indivíduo/estado, prejudica o trabalho/serviço.

Na maioria das vezes, no ambiente de trabalho, o assédio moral ocorre com atitudes de chefias tiranas, que não atentam para os prejuízos que causam; nem tampouco tem noção da dimensão do erro que cometem quando exploram o subordinado visando fins pessoais, principalmente os seus próprios sucessos. Exploram, assim, excessivamente o subordinado, atribuindo-lhe atividades que não são de sua competência, não respeitando seus horários de trabalho e nem proporcionando condições operacionais compatíveis com as tarefas impostas.

Essa exploração excessiva traz consequência gravíssima para a saúde do subordinado, a chamada doença ocupacional conhecida como Síndrome de Burnout ${ }^{4}$. Essa doença caracterizada pelo esgotamento físico, psíquico e emocional, em decorrência de trabalho em condições muito estressantes, causa distúrbios mentais e psíquicos que tem como efeitos: estresse, hipertensão arterial, perda de memória, ganho de peso e depressão, entre outros problemas. A Declaração Universal dos Direitos Humanos da ONU, no seu art. I, afirma: “Todos os seres humanos nascem livres e iguais em dignidade e em direitos. Dotados de razão e de consciência, devem agir uns para com os outros em espírito de fraternidade". Portanto, humanamente, não se justifica o comportamento abusivo dessas chefias. Não se justifica ainda porque, legalmente, fere o Estatuto do Servidor Público, lei n. 8.112, de 11 de dezembro de 1990, principalmente, os incisos III, IX e XI do art. 116, combinados com os incisos IX, XV, XVI e XVII do art. 117 dessa mesma Lei.

\footnotetext{
4 A Síndrome de Burnout é um termo psicológico que descreve o estado de exaustão prolongada e diminuição de interesse, especialmente em relação ao trabalho, que segundo Maslach (1994) é desenvolvida em resposta a fontes crônicas de estresse emocional e interpessoal no trabalho. O termo "burnout" (do inglês "combustão completa") descreve principalmente a sensação de exaustão da pessoa acometida.
} 
O comportamento acima leva, indubitavelmente, à prática da gestão perversa, conforme definição de Ferreira (2006, p. 17):

“algumas características da gestão perversa nas organizações são falta de comunicação; pessoas que são colocadas em situação de rivalidade; manipulação de pessoas, para que se desestruturem e autodestruam; diminuição do número de cargos, exigindo cada vez mais produtividade; e o fato de não agirem de forma direta e clara." Ferreira (2006, p. 17)

Sendo o assédio moral um fenômeno que atinge todas as camadas sociais e que acontece em quase todos ambientes de trabalho, pretende-se com essa pesquisa avaliar se esse fenômeno existe no ambiente de trabalho da UnB, e quais as consequências na saúde física e psicológica do servidor. E, se existe, espera-se conhecer as formas diferentes de assédio moral entre os sexos; a relação de trabalho entre os envolvidos; os prejuízos sofridos; se por motivo de doença houve assédio; se na UnB há alguma forma de divulgação sobre assédio moral; o vínculo dos envolvidos com a UnB e a escolaridade dos envolvidos.

Sob esse enfoque, é de se considerar que a UnB como instituição educacional preza por firmar a sua missão: "Produzir, integrar e divulgar conhecimento, formando cidadãos comprometidos com a ética, a responsabilidade social e o desenvolvimento sustentável."; os seus valores: "Ética e respeito à diversidade. [...] com transparência e responsabilidade social. Busca permanente de excelência. Universalização do acesso. Respeito à dignidade, à liberdade intelectual e às diferenças. Preservação e valorização da vida." ${ }^{5}$

$5<$ http://www.unb.br/unb/missao.php > Acessado em 20 de maio de 2010. 


\section{ASSÉDIO MORAL E A VIOLÊNCIA FÍSICA E PSICOLÓGICA}

Procurando identificar mais profundamente esse fenômeno, para a maioria dos pesquisadores modernos, o assédio moral é um fato da sociedade contemporânea. Contudo o fenômeno é mais antigo. Analisando a história do mundo, verifica-se que esse tipo de abuso vem desde os primórdios quando os povos vencidos em batalhas eram escravizados por seus conquistadores e eram obrigados a trabalhar de forma cruel em afazeres rudimentares. O sistema feudal também produziu muitos abusos na relação senhor/servo. As relações servis eram extremamente desfavoráveis - extremamente abusivas, na ótica de hoje - à parte mais fraca: os servos. Já na época em que os portugueses começaram a colonização do Brasil, eles usaram o trabalho dos índios nas lavouras, numa relação de superior/inferior bastante abusiva, provocando revolta naqueles indígenas. O mesmo fizeram quando se voltaram para os negros trazidos da África, submetendo-os ao trabalho escravo aqui na colônia, provocando traumas sociais que até hoje repercutem em nossa sociedade.

Nesse breve histórico percebe-se que a conduta abusiva, principalmente em termos como hoje é conhecida, é um fenômeno antigo que ainda continua acontecendo nos ambientes de trabalho. Os abusos persistem, apenas mudando de roupagem em razão da evolução e interesses do sistema econômico/financeiro mundial.

Essa preponderância do sistema econômico/financeiro mundial leva, invariavelmente, à exploração desmedida do homem pelo homem, em suas relações interpessoais no espaço de trabalho quando se perde de vista os valores humanos. O resultado é a colocação do ser humano em situações humilhantes e constrangedoras, que passa a ser tratado como "coisa”. E na situação de "coisa" é tratado como objeto descartável dentro da estrutura organizacional.

Vários estudos já constataram que esse tipo de conduta abusiva é bastante expressivo em todos os setores da sociedade. A maioria das vítimas sequer tem conhecimento dos seus direitos e, portanto, não sabem como se defender. Mesmo aqueles que têm consciência desses abusos no ambiente de trabalho preferem calar, porque dependem do emprego para viver e, tem medo de represálias vingativas. 
Esse comportamento é reforçado com as novas relações de trabalho, em virtude do crescimento acelerado na economia juntamente com as rápidas mudanças no campo da ciência e da tecnologia, facilitando a produção em massa. Com isso, o trabalhador é forçado a produzir mais e mais e a ter que tornar a sua força de trabalho necessária, a fim de garantir o seu emprego. Dessa forma, diante da grande competitividade no mercado de trabalho o homem perde a sua identidade e passa a se transformar numa máquina.

Já nas instituições públicas, um dos fatores preponderantes que contribuem para esse tipo de conduta abusiva é a estabilidade no emprego. As pessoas se sentem mais seguras para cometer abusos, pois sabem que o processo contra elas é de difícil comprovação, e quase sempre muito demorado. Contam ainda com corporativismo. Disso se valem muitos chefes que, para promoverem o seu sucesso pessoal, acometem seus subordinados com atividades excessivas, incompatíveis em si, e fora das obrigações regulamentares ou estatutárias a que normalmente estariam obrigados. Quando não, usam de artifícios, estimulando a vaidade de certos subordinados a fim de provocar no grupo um ambiente de competitividade agressivo e degradante entre colegas de trabalho.

\subsection{Assédio moral: espécies, tipos de agressores e estratégias dos assediadores}

Por incrível que pareça, muitos, apesar de não admitirem, desconhecem as características do assédio moral. Logo, o ambiente de trabalho pode estar contaminado com comportamentos abusivos, sem que haja uma consciência coletiva do fenômeno.

Por isso o binômio assediador/assediado nem sempre é notado pelos atores envolvidos, ou por um deles ou pelos demais. Por sua vez, o assediado, por não haver no ambiente de trabalho tal percepção, passa a conviver com essa situação de sofrimento sem se aperceber do absurdo, chegando até, equivocadamente, a se julgar incapaz, pensando que é responsável pela situação em que se encontra.

Logo, é importante distinguir as espécies de assédio moral e tipos de agressores, para melhor poder identificar o fenômeno no local de trabalho.

O assédio moral, como é tratado nessa monografia, tem o sentido ou conceito apresentados nas páginas anteriores. Na sua forma de violência psicológica se apresenta, mui- 
tas das vezes, como racismo ou qualquer outra forma de preconceito ou sectarismo, deixando de ser abordado aqui por fugir ao escopo dessa monografia.

Dessa forma, verifica-se que o assédio moral se manifesta em razão de diversas relações interpessoais. A forma mais conhecida de agressão ocorre entre superiores e subordinados. Contudo, as agressões, dependendo do tipo de assédio, podem assim se caracterizar:

- um superior ou grupo de superiores agride um subordinado ou grupo de subordinados (assédio vertical);

- um colega ou grupo de colegas agride outro colega ou outro grupo de colegas (assédio horizontal);

- um superior ou grupo de superiores é agredido por um subordinado ou grupo de subordinados (assédio vertical); quando há confusão de ações envolvendo componentes das três classificações acima, temos o assédio misto. ${ }^{6}$

Apesar de o assédio moral ter componentes físicos e psicológicos, procurou-se ressaltar nesta monografia o aspecto psicológico.

Observando-se por esse aspecto, percebe-se que os assediadores, para atigirem os seus fins em geral procuram humilhar as vítimas.

No assédio horizontal, quando os assediadores são colegas da(s) vítima(s), procuram ressaltar suas deficiências, sejam físicas, intelectuais ou profissionais, geralmente adotando condutas semelhantes a:

- fazer discriminação do(s) colega(s);

- assumir uma postura individualista;

- tratar com indiferença o(s) colega(s);

- boicotar a disseminação de informações úteis ou necessárias;

- discriminar o(s) colega(s) em razão do gênero;

- $\quad$ ter atitudes preconceituosas; entre outras ${ }^{7}$ 
Quando o assédio é vertical, isto é, chefes ou superiores contra subordinados ou inferiores e vice-e-versa, as possibilidades são inúmeras. As condutas mais comuns, dentre outras, são:

- passar instruções (informações) confusas e imprecisas;

- criar dificuldades para a realização do(s) trabalho(s);

- atribuir erros imaginários aos subordinados ou aos chefes;

- exigir, sem necessidade, trabalhos urgentes ou provocar urgências desnecessárias;

- impor sobrecarga de tarefas aos subordinados, ou atrasar, deliberadamente a execução de tarefas;

- ignorar a presença do(s) subordinado(s) ou do(s) chefe(s);

- não cumprimentar deliberadamente e/ou não dirigir a palavra ao(s) subordinado(s) ou ao(s) chefe(s) quando na frente de outro(s);

- fazer críticas ou brincadeiras de mau gosto contra o(s) subordinado(s) ou chefe(s) em público;

- impor horários injustificados;

- retirar do(s) subordinado(s) injustificadamente, os instrumentos de trabalho;

- agredir física ou verbalmente, quando a sós, o(s) subordinado(s) ou chefe(s);

- determinar revista vexatória;

- restringir o uso de sanitários;

- fazer ameaças;

- promover insultos;

- determinar o isolamento do(s) subordinado(s) ${ }^{8}$

Geralmente, o assédio moral se desenvolve em quatro fazes: na primeira é estabelecido um conflito de interesses abusivo (vertical, horizontal ou misto). Daí, segue-se a segunda fase, onde o agressor desenvolve sua estratégia, visando humilhar a(s) vítima(s), valendo-se de comportamentos perversos (sem ética), com a finalidade de ridicularizar e isolar a(s) vítima(s) dos demais. Quase sempre essa(s) vítima(s) não se dá conta do que está acontecendo, chegando até mesmo a negar os fatos perante os demais. Nesse ponto, deve haver uma 
intervenção da Instituição ou empresa, provocada por quem melhor identificar o fato, i.e., autoridade superior aos conflitantes. Caso essa intervenção não exista ou venha a ser falha, segue-se a quarta fase, onde é visada a marginalização da(s) vítima(s) ou até a exclusão dela(s) do ambiente de trabalho. As consequências para a(s) vítima(s) serão abordadas no decorrer desse trabalho.

Como exemplo do conflito de interesses, a estratégia usada pelos assediadores contra o trabalhador ou grupo de trabalhadores não estáveis, a fim de que ele desista do emprego, do cargo ou seja removido do local de trabalho está bem caracterizado nas palavras da pesquisadora Barreto (2006) quando diz que assédio moral:

"é a exposição dos trabalhadores e trabalhadoras a situações humilhantes e constrangedoras, repetitivas e prolongadas durante a jornada de trabalho e no exercício de suas funções, sendo mais comuns em relações hierárquicas autoritárias e assimétricas, em que predominam condutas negativas, relações desumanas e aéticas de longa duração, de um ou mais chefes, dirigida a um ou mais subordinado(s), desestabilizando a relação da vítima com o ambiente de trabalho e a organização, forçando-a a desistir do emprego."

Contudo, seja qual for o tipo de emprego, quando na terceira fase a Instituição ou empresa não intervém para solucionar o conflito, falhando na identificação do assédio moral, o ambiente de trabalho marcha para a marginalização da(s) vítima(s). Às vezes essa(s) vítima(s), quando se apercebem do que está ocorrendo, procura(m) apoio em seus pares ou até mesmo em outro(s) superior(es). Porém, estes, por medo do desemprego e da vergonha de serem também humilhados, juntamente com o constante estímulo à competitividade (seja malicioso ou natural), rompem os laços afetivos (se houver) com a(s) vítima(s), e, a seguir, quase sempre, passam a reproduzir e reatualizar as ações e os atos do(s) agressor(es) no ambiente de trabalho.

Dessa forma, o coletivo silencia enquanto a vítima vai gradativamente se desestabilizando e se fragilizando; perdendo a naturalidade, a alegria, a criatividade e a iniciativa; ficando, quase sempre, apática e depressiva. 
Esse processo de humilhação, quando repetitivo, interfere diretamente na vida da vítima, causando danos à sua dignidade, prejudicando sua identidade e relações afetivas e sociais, com repercussão na sua saúde física, psíquica ou mental. Consequentemente, podem provocar a diminuição da sua capacidade laborativa, com prejuízos para todos.

Naturalmente, humilhação como ato isolado não é assédio moral. Esse se caracteriza por certos comportamentos ${ }^{9} \mathrm{do}(\mathrm{s})$ agente(s) agressor(es), tais quais:

- degradação deliberada das condições de trabalho;

- direcionalidade (uma ou um grupo de pessoas é escolhida por uma ou um outro grupo de pessoas como bode expiatório);

- intencionalidade (forçar o outro a abrir mão do emprego);

- repetição sistemática;

- temporalidade (durante a jornada, por dias e meses).

Sobre esse processo de degradação dos seres humanos no ambiente de trabalho, a médica do trabalho Dra Margarida M. Silveira Barreto, pontua:

“[... quando o homem prefere a morte à perda da dignidade, se percebe muito bem como saúde, trabalho, emoções, ética e significado social se configuram num mesmo ato revelando a patogenicidade da humilhação [...]”. Barreto (2000, p. 242).

Casos especiais desse processo de humilhação são utilizados de diversas formas. Uma delas é quando o assediador é simplesmente narcisista, trazendo ocultamente o desejo de ser reconhecido como o melhor. Exige que todos no ambiente de trabalho o admirem. Aqueles que demonstrem indiferença ou mesmo aponte suas falhas são literalmente perseguidos. Para isso, o assediador utiliza-se de todos os artifícios morais e imorais, principalmente os poderes que possuem em razão do serviço. Disso decorre que é importante identificar as características próprias de pessoas narcisistas, a fim de se evitar comportamentos abusivos:

- arrogância nas atitudes e comportamentos;

- fantasias ilimitadas de êxito e poder;

- idéias grandiosas de sua própria importância; 
- necessidade excessiva de ser admirado. ${ }^{10}$

Outro caso especial de assédio moral é quando ele se manifesta na forma de assédio sexual. Notadamente na forma de piadas e comentários picantes, carícias ou pedidos de favores sexuais indesejáveis que, quando não atendidos, são seguidos de represálias, recusa de promoção ou, até mesmo, afastamento da vítima do ambiente de seu trabalho, se servidor estável; demissão, se empresa privada.

Essa forma de assédio moral é importante ser caracterizada aqui, porque a sua manifestação quase sempre é dissimulada, consistindo seu tipo penal em:

"Constranger alguém com o intuito de obter vantagem ou favorecimento sexual, prevalecendo-se o agente da sua condição de superior hierárquico ou ascendência inerentes ao exercício de emprego, cargo ou função."

Assim, cada vez mais existem evidências de que a violência não física, ou seja, as formas predominantemente psicológicas sejam mais frequentes que os ataques físicos.

Os estudos também tem demonstrado que essa violência psicológica produz efeitos devastadores para os seus alvos, mais que a violência física. Essas situações de violência psicológica além de prejudicarem as vítimas gravemente, também interferem nas pessoas que presenciam esses comportamentos: amigos, pessoas da família e das relações de trabalho.

Existem outras formas veladas de violência psicológica: abuso emocional, terror psicológico, assédio moral ou assédio psicológico e, com mais estudos no exterior, no bull$y_{i n g}{ }^{11}$ e no mobbing ${ }^{12}$. Tudo isso trata do mesmo fenômeno, e não existe para eles uma defini-

10 http://wapedia.mobi/pt/Ass\%C3\%A9dio_moral > Acessado em 15 de junho de 2010.

$11 \mathrm{http}: / /$ www.avbdesign.com/assedio/oquee.html Acessado em 22 de maio de 2010. Quanto ao bullying significa na Wikipedia: ameaça, intimidação. Bullying é um termo de origem inglesa utilizado para descrever atos de violência física ou psicológica, intencionais e repetidos, praticados por um indivíduo (bully) ou grupo de indivíduos com o objetivo de intimidar ou agredir outro indivíduo (ou grupo de indivíduos) incapaz/es de se defender. A palavra "Bully" significa "valentão", o autor das agressões. A vítima, ou alvo, é a que sofre os efeitos delas. Também existem as vítimas/agressoras, ou autores/alvos, que em determinados momentos cometem agressões, porém também são vítimas de bullying pela turma. http://pt.wikipedia.org/wiki/Bullying Acessado em: 22 de maio de 2010.

12 A palavra mobbing deriva do verbo inglês to mob que, em português, significa atacar, maltratar, tratar mal alguém, cercar, rodear, tumultuar e amotinar. Segundo Leymann (1990, p. 121) mobbing é "o fenômeno no qual uma pessoa ou grupo de pessoas exerce violência psicológica extrema, de foram sistemática e recorrente e durante um tempo prolongado - por mais de seis meses e que os ataques se repitam numa freqüência média de duas vezes na semana - sobre outra pessoa no local de 
ção que tenha um consenso comum. Porém todas concordam que assédio psicológico é: "um comportamento persistente, ofensivo, abusivo, intimidatório, malicioso ou insultuoso, abuso de poder ou sanções injustas, que fazem com que o agredido se sinta preocupado, ameaçado, humilhado ou vulnerável, minando a sua autoconfiança e provocando-lhe estresse." Viana (2009) apud Aguiar (2006) esclarece que:

“[...] a violência psicológica é aplicada frequentemente aos indivíduos no ambiente em que desenvolvem suas atividades profissionais, considerando os registros documentais dessas perversidades, nas relações interpessoais daqueles universos organizacionais, amiúde calçada no temor, na obediência cega aos manuais burocrático, no medo, na disputa, na inveja e na concorrência entre os pares." ${ }^{13}$

Do bullying, Sandra Maura ${ }^{14}$, da Topmind ${ }^{15}$ explica que: “assim como o assédio moral, muitos gestores não sabem identificar o bullying, também caracterizado por atitudes agressivas, intencionais e repetidas, que ocorrem sem motivação evidente, e que são executadas dentro de uma relação desigual de poder. Ambas envolvem a contínua ridicularização do outro e há a cumplicidade do grupo no qual o profissional está inserido. Contudo, os processos de bullying podem ir além dos insultos verbais e chegar às agressões físicas.”

Esclarecendo um pouco mais o assunto, a Task Force on the Prevention of Workplace Bullying ${ }^{16}$, que é um órgão com ligações à Agência Européia para Segurança e Saúde no Trabalho, definiu assédio psicológico como um "comportamento inapropriado repetitivo, direto ou indireto, verbal ou físico, exibido por uma ou mais pessoas, contra uma ou mais

trabalho, com a finalidade de destruir as redes de comunicação da vítima ou vítimas, destruir sua reputação, perturbar a execução de seu trabalho e conseguir finalmente que essa pessoa ou pessoas acabe abandonando o local de trabalho.”

13 VIANA Danielle Fabiana dos Santos. As causas e conseqüências do assédio moral nas organizações.< http://www.administradores.com.br/informe-se/artigos/causas-e-consequencias-do-assedio-moral-nas-organizacoes/27496/ $>$ Acessado em 22 de maio de 2010.

$14<$ http://revistamelhor.uol.com.br/textos.asp?codigo=12360 >, Sandra Maura, diretora executiva da TOPMIND, empresa que atua nos segmentos de Tecnologia da Informação, Telecom e Recursos Humanos Estratégico. Acessado em 22 de maio de 2010.

15 < http://www.topmind.com.br/ >, Topmind, empresa que atua nos segmentos de tecnologia da informação e telecomunicações.

16 A task force on the prevention of workplace bullying was established in Ireland in 1998 by the Irish Minister for Labour, Trade and Consumer Affairs. The aim was to investigate the problem of bullying and to develop comprehensive and applicable recommendations on how to tackle it most effectively.< http://osha.europa.eu/data/case-studies/task-force-on-the-preventionof-work-place-bullying > Acessado em: 22 de maio de 2010. Tradução livre: A força tarefa para prevenção do bullying no local de trabalho foi criada na Irlanda em 1998 pelo Ministro do Trabalho, Comércio e Consumo. O objetivo foi investigar o problema do bullying e desenvolver recomendações abrangentes e aplicáveis para evitar o bullying com mais eficiência. 
pessoas, no local de trabalho, que pode ser visto, em termos razoáveis, como contrariando o direito do indivíduo à dignidade no trabalho.”

No entanto, muito dessa violência poderia ser evitado se não houvesse omissão das instituições diante desse fenômeno. Felizmente, apesarde ser tratado com indiferença em algumas instituições públicas, existem outras preocupadas com o problema. A exemplo, a UNIRIO - Universidade Federal do Estado do Rio de Janeiro, que criou normas para coibir o assédio moral no seu campus e vem mostrando que é possível haver uma política de prevenção nas instituições públicas e privadas.

No caso da UNIRIO, com a Ordem de Serviço Gr interna no ${ }^{\circ} .02,{ }^{17}$ de 13 de janeiro de 2004, o reitor dispõe sobre os procedimentos a serem adotados em casos de assédio moral, respeitando a legislação federal. Dessa forma, torna-se a primeira universidade em nosso país a dar o exemplo de enfrentamento do problema, com normas para disciplinamento do seu corpo discente, docente e técnico-administrativo.

A tolerância desses tipos de relações no trabalho acarreta um decréscimo de desempenho funcional do indivíduo, trazendo prejuízos para todos - o indivíduo, as instituições e, consequentemente, a sociedade.

Como se vê, vários estudos mostram que esse fenômeno no ambiente de trabalho é responsável por diversos tipos de problemas de saúde. As psíquicas: o estresse, e principalmente a depressão, são responsáveis diretos pela baixa autoestima; perda do interesse, da alegria e da criatividade ${ }^{18}$ para com o trabalho e do absenteísmo. As físicas, como pressão-alta, processos alérgicos, obesidade mórbida, anorexia, problemas do coração, mesmo que, às vezes, resultantes das psíquicas, todas formam um conjunto de fatores que conduz, muita vezes, à desistência do emprego ou, até mesmo, à morte e ao próprio suicídio.

Assim, para evitar que o trabalhador venha a se enquadrar no que foi acima descrito, e esteja plenamente apto para o trabalho, precisa de garantias que impeçam condutas abusivas no seu ambiente de trabalho. Um dos aspectos mais importantes nas relações interpessoais do dia-

$17<$ http://www.assediomoral.org/spip.php?article186 > Acessado em 22 de maio de 2010. UNIRIO dispõe sobre os procedimentos a serem adotados em casos de assédio moral.

18 Aguiar (2006) explica que “[...] Trabalhador doente, perseguido, maltratado, humilhado não é criativo. Para ser criativo é essencial o bem-estar no local de trabalho [...]." 
a-dia é o respeito. Respeito, nesse caso, significa obediência às normas - direitos e deveres - sejam superiores, subordinados, colegas, todos devem se pautar de acordo com suas competências, respeitando os limites regulamentares, legais e civilizados.

A despeito de sermos civilizados e haver leis e regulamentos, é preciso, no entanto, reconhecer que o assédio moral não é suficientemente percebido ou é ardilosamente camuflado. Superar essa falsa percepção sobre o assédio moral no trabalho é evitar a banalização do problema.

Seria razoável, no mínimo, tomar atitudes prospectivas, levando em conta a possibilidade de estar havendo esse fenômeno abusivo. Isso seria uma das formas de se evitar que esse mal seja banalizado no ambiente de trabalho. Nesse sentido, a psicanalista e pesquisadora francesa Hirigoyen (2000) observa que há diferentes formas de sofrimento psicológico no trabalho provocados pelo assédio moral, não importando quão avançada seja legislação protetiva do trabalhador de cada país.

Portanto, é de fundamental importância um estudo verificador sobre a existência do assédio moral no ambiente de trabalho da UnB e quais as consequências na saúde física e psicológica do servidor. Também é necessário se criar uma política de conscientização e reflexão em todos aqueles que fazem parte do contexto universitário.

\subsection{Consequências do assédio moral}

As consequências desse fenômeno são desastrosas para todos: à vítima (com todo o seu universo particular: família e sua vida social), o assediador, à empresa ou instituição e à sociedade.

Inconscientemente a vítima sofre, sem entender o seu próprio sofrimento. Razão disso é a sensação de perda da dignidade que a coloca na condição de não perceber a dominação psicológica do agressor, nem a sua submissão. Essa situação é a principal causadora do sofrimento psicológico que traz como consequências, entre outras: insônia; aparente can- 
saço, condutas de dependência como a bulimia ${ }^{19}$, alcoolismo, toxicomania, estresse, ansiedade generalizada, fadiga crônica, depressão, e distúrbios psíquicos diversos.

Quando a vítima toma conhecimento da realidade dos fatos, fica atemorizada, desamparada, confusa e muitas vezes traumatizada. Hirigoyen (2002, p. 176.) descreve esse estado com maestria: “[...] é uma sensação de rompimento violenta, de estupefação, de transbordamento, ou de desmoronamento, que certas vítimas descrevem como sendo quase uma agressão física: é como um murro [...]”.

Nesse estado de confusão, a vítima não consegue sair do emaranhado em que se encontra. Por isso, quase sempre, vem a depressão. Muitas se isolam do grupo a que pertencem. Nessa solidão, diante do sofrimento, sem coragem de pedir ajuda ou quando pede não é levada a sério, a vítima não consegue reagir às agressões sofridas no seu ambiente de trabalho. Surge daí a dificuldade para desempenhar suas funções com qualidade, seja na vida particular, seja na vida profissional.

Mais uma vez a pesquisadora e psiquiatra francesa Marie-France Hirigoyen descreve com sensibilidade os sentimos da vítima:

“As agressões ou humilhações permanecem inscritas na memória e são revividas por imagem, pensamentos, emoções intensas e repetitivas, seja durante o dia, com impressões bruscas de iminência de uma repetição idêntica, ou durante o sono, provocando insônias e pesadelos. As vítimas tem necessidades de falar dos acontecimentos traumatizantes, mas a evocações do passado levam, todas as vezes, às manifestações psicossomáticas equivalentes ao medo. Elas apresentam distúrbio de memória e de concentração. Por vezes perdem o apetite, ou tem, pelo contrário, condutas bulímicas, que aumentam seu consumo de álcool ou de fumo." Hirigoyen (2002, p.183).

O agressor, por possuir um comportamento psicopático, não tem consciência do prejuízo que causa, portanto é um doente que precisa de tratamento e/ou ser afastado do ambiente de trabalho. Isso é verdade mesmo quando o agressor é um grupo, pois o grupo adota o comportamento de assediador nos termos do fenômeno mobbing.

19 Distúrbio do apetite caracterizado por episódios incontroláveis, chamados de acessos de hiperfagia, que, independentemente da anorexia nervosa, sobrevêm ao menos duas vezes por semana durante três meses ou mais 
Os prejuízos são, também, para a empresa ou instituição que fica na iminência de sofrer perdas com pessoal; com aumento nas despesas previdenciárias, nas despesas com serviços jurídicos, principalmente em defesas perante à Justiça (uma vez que o assédio moral é uma espécie de quebra de contrato), na redução da produção ou na eficiência dos serviços prestados, e, outros mais; com o desgaste perante o seu público alvo, clientes de sua produção ou serviços.

Perde, principalmente, a sociedade, pois os custos sociais são imensos, advindos da manutenção de aparatos de saúde para atendimento da clientela assediada e com aposentadorias precoces; por ter serviços e produtos com baixa qualidade e, o mais importante, por ter parcela de sua população sofrendo, com reflexos na paz social esperada.

Dessa forma, o assédio moral atinge a sociedade como um todo, conforme já dissertado. Por essa razão, deve ser identificado, analisado e combatido com veemência, a fim de se minimizar os efeitos prejudiciais à convivência humana.

\subsection{A legislação, aspectos jurídicos e éticos para proteção contra o assédio}

No Brasil já existem várias leis específicas ${ }^{20}$ de proteção contra o assédio moral. A grande maioria é municipal e geralmente voltadas para os servidores públicos. A seguir é apresentada como exemplo uma listagem das leis já em vigor nos municípios que discrimina.

Lei 3.243 de 15/05/2001 - Cascavel - PR;

Lei no 358 de 19/07/2001 - Guarulhos - SP;

Lei no 1.078 de 05/11/2001 - Sidrolândia -MS;

Lei no 2.982 de 17/11/2001 - Jaboticabal -SP;

Lei no 13.288 de 10/01/2002 - São Paulo -SP;

Lei no 189 de 23/02/2002 - Natal -RN;

Lei no 3.671 de 07/06/2002 - Americana - SP;

Lei no 3.921de 23/08/2002 - Rio de Janeiro -RJ;

Lei no 11.409 de 04/11/2002 - Campinas -SP;

Lei no 2.949, de 19/04/2002 - Distrito Federal -DF;

Lei no 511 de 04/04/2003 - São Gabriel do Oeste -MT;

Lei no 13.261 de 12/12/2003 - São Carlos -SP. 
Outras leis estão tramitando pelas diversas casas legislativas do país, na forma de projetos de lei.

$\mathrm{Na}$ esfera federal não há lei específica para o tema. Existem alguns projetos tramitando nas casas legislativas, porém ainda não se produziu qualquer lei. No entanto, para a proteção geral da intimidade, da vida privada, da honra e da imagem de qualquer pessoas, há suficientes instrumentos legais no ordenamento jurídico nacional.

Para isso se recorre à legislação genérica que é a mesma inerente aos direitos do cidadão geral. Para efeito de orientação, segue abaixo uma relação que não pretende ser exaustiva e única.

Constituição da República Federativa do Brasil de 1988.

Código Civil Brasileiro - Lei no 10.406 de 10 de janeiro de 2002.

Código Penal Brasileiro - Lei no 2.848 de 7 de dezembro 1948.

Decreto-Lei no. 5.452 de $1^{\circ}$. de maio de 1943.

Estatuto dos Servidores Públicos Civis da União - Lei nº. 8.112 de 11 de dezembro de 1990.

Normas internas das organizações ou instituições.

Os direitos individuais e coletivos devem ser observado primeiramente nos textos a seguir: Constituição da República Federativa do Brasil (CF), os códigos civil (CCB) e penal (CPB), Consolidação das Leis Trabalhistas (CLT), Estatuto do Servidor Público que são, hoje dia, diplomas legais necessários para se discutir a violência do assédio moral nos tribunais. Assim, será exemplificado um roteiro de dispositivos constitucionais e legais que servirão de base para se enfrentar condutas abusivas no ambiente de trabalho.

Começa-se com o fundamento da dignidade do ser humano e do trabalho, que está disposto primeiramente na CF/1988, litteris: “Art. 1 A República Federativa do Brasil [...] e tem como fundamentos: III - a dignidade da pessoa humana; IV - os valores sociais do trabalho [...];”. Só por esses fundamentos há procedência, na Justiça, de qualquer ação de indenização ou proteção contra condutas abusivas no ambiente de trabalho, quando violados esses direitos fundamentais do cidadão. 
Com relação ao trabalho, o art. $6^{\circ}$. da CF/1988 enfatiza ser esse um direito social, logo está sob proteção constitucional e nenhuma conduta abusiva pode atentar contra a segurança da vítima na manutenção de seu trabalho. Nesse sentido, o art. $7^{\circ}$. da indigitada constituição, no seu inciso I, afirma que a relação de emprego é protegida contra despedida arbitrária ou sem justa causa, prevendo uma indenização compensatória, disciplinada e lei.

O processo de desenvolvimento do assédio moral produz naturalmente uma cadeia de intromissões ilícitas externas, que atingem não só a vida privada e a imagem da vítima, como também suas relações sociais e familiares. Logo, para inibição desse processo ou reparação dos danos já causados ou em andamento, o art. 5º da CF/1988 caput e seus dois incisos, $\mathrm{V}$ e X, são essenciais para a proteção constitucional da privacidade do cidadão. E dispõe, litteris:

“Art. $5^{\circ}$ Todos são iguais perante a lei, sem distinção de qualquer na-
tureza, garantindo-se aos brasileiros e aos estrangeiros residentes no
País a inviolabilidade do direito à vida, à liberdade, à igualdade, à se-
gurança e à propriedade, nos termos seguintes:
V - é assegurado o direito de resposta, proporcional ao agravo, além da
indenização por dano material, moral ou à imagem;
[...]
X - são invioláveis a intimidade, a vida privada, a honra e a imagem
das pessoas, assegurado o direito a indenização pelo dano material ou
moral decorrente de sua violação;"

Apesar de o inciso V ser mais utilizado para o direito de resposta decorrente de danos provocados por atividades de comunicação, jornalísticas, de imprensa, é extensivo, de um modo geral, à fundamentação de pedido de indenização ou reparação de danos por assédio moral, considerando que essa conduta abusiva coloca a vítima em situação de humilhação no ambiente de trabalho, perante os familiares, os amigos etc.

Tendo em vista ainda que o assédio moral afeta diretamente a dignidade do ser humano, degradando sua imagem, sua honra, tanto objetiva quanto subjetiva, é relevante ter em conta que o processo de indenização se apóie no inciso X do indigitado artigo.

Dessa forma, percebe-se que os dispositivos constitucionais: arts. $1^{\circ}$. nos seus incisos III e IV, combinados com o art. $5^{\circ}$., caput, e seus incisos V e X formam a base para se 
propor ações reparadoras tanto na Justiça quanto na via administrativa contra assédio moral ações essas que tem caráter inibidor de comportamentos abusivos.

É preciso cuidar que, tanto omissões quanto ações, quando causas da existência de condutas abusivas e conseqüente dano à(s) vítima(s), dão motivo à reparações na esfera jurídica. Não importa se a responsabilidade é subjetiva ou objetiva. No caso concreto, se aquilatará o tipo. O que importa é que há instrumentos legais para a reparação civil e penal.

As bases civis do questionamento na Justiça, começam pela Lei $\mathrm{n}^{\circ}$. 10.406, de 10/01/2002, Código Civil Brasileiro, no título Dos Atos Ilícitos, art. 186., dispõe, litteris: “Art. 186. Aquele que, por ação ou omissão voluntária, negligência ou imprudência, violar direito é causar dano a outrem, ainda que exclusivamente moral, comete ato ilícito." Essa disposição e complementada pelo art. 187 do mesmo diploma, litteris: "Art. 187. Também comete ato ilícito o titular de um direito que, ao exercê-lo, excede manifestamente os limites impostos pelo seu fim econômico ou social, pela boa-fé ou pelos bons costumes.” E o art. 927 do CCB declara e reafirma a obrigação de indenizar.

A reparação decorrente da quebra de fórmulas contratuais ou estatutárias, também é disciplina no diploma civil, no título que trata Do Inadimplemento das Obrigações, art. 389, litteris “Art. 389. Não cumprida a obrigação, responde o devedor por perdas e danos, mais juros e atualização monetária segundo índices oficiais regularmente estabelecidos, e honorários de advogado."

Não se deve perder de vista os ditames da ética. Quando a empresa ou a instituição, bem como o(s) agressor(es) não procedem conforme é regulamentado ou naturalmente esperado, causam estupefação, pois violam a ética, principalmente a ética individual. Não são as organizações ou instituições que vitimizam, mas as pessoas que as mobiliam. Essas pessoas tendo boa índole ou bom caráter naturalmente não preencherão o perfil de assediador.

Porém, o mundo não é mobiliado só por pessoas de bom caráter ou boa índole. Ao contrário, o que temos, geralmente, é um mescla, e, nessa mescla, se destaca o assediador. Se destaca porque seu comportamento é ativo, incisivo e dirigido ao fim. Nesse processo, o assediador moral se mostra como uma pessoa negativamente impulsiva, perversa, pois se deli- 
cia com o sofrimento da vítima, demonstrando falta de caráter; consequentemente é um ser humano aético.

Violação da ética pode ser intencional, então se dá a má-fé. Ou em razão de negligência, isto é, descumprimento do(s) regulamento(s), no sentido de que ocorre a falta de respeito para com a vítima ou mesmo para com os fins organizacionais ou institucionais. De qualquer forma, é um comportamento aético que produz danos e devem ser reparados, a fim de que não se repitam. Desse tema cuida o art. 422 do CCB, litteris: "Art. 422. Os contratantes são obrigados a guardar, assim na conclusão do contrato, como em sua execução, os princípios de probidade e boa-fé."

As instituições, entre elas as empresas, estão obrigadas a reparar os danos provocados por seus prepostos. Isso, hoje, não mais se discute.

Para garantia desse direito, legalmente os arts. 932, III e 933 do CCB, são os que socorrem a vítima, litteris:

“Art. 932. São também responsáveis pela reparação civil:

[...]

III - o empregador ou comitente, por seus empregados, serviçais e prepostos, no exercício do trabalho que lhes competir, ou em razão dele;

[...]

Art. 933. As pessoas indicadas nos incisos I a V do artigo antecedente, ainda que não haja culpa de sua parte, responderão pelos atos praticados pelos terceiros ali referidos."

No tocante à parte trabalhista, a CLT no art. 483 , litteris: “

Art. 483. O empregado poderá considerar rescindido o contrato e pleitear a devida indenização quando:

a) forem exigidos serviços superiores às suas forças, defesos por lei, contrário aos bons costumes, ou alheios ao contrato;

b) for tratado pelo empregador ou por seus superiores hierárquicos com rigor excessivo;

c) correr perigo manifesto de mal considerável;

d) não cumprir o empregador as obrigações do contrato;

e) praticar o empregador ou seus prepostos, contra ele ou pessoas de sua família, ato lesivo da honra e boa fama; 
f) o empregador ou seus prepostos ofenderem-no fisicamente, salvo em caso de legítima defesa, própria ou de outrem;

g) o empregador reduzir o seu trabalho, sendo este por peça ou tarefa, de forma a afetar sensivelmente a importância dos salários.

$\$ 1^{\circ} \mathrm{O}$ empregado poderá suspender a prestação dos serviços ou rescindir o contrato, quando tiver de desempenhar obrigações legais, incompatíveis com a continuação do serviço.

$\S 2^{\circ}$ No caso de morte do empregador constituído em empresa individual, é facultado ao empregado rescindir o contrato de trabalho.

$\$ 3^{\circ}$ Nas hipóteses das letras d e g, poderá o empregado pleitear a rescisão de seu contrato de trabalho e o pagamento das respectivas indenizações, permanecendo ou não no serviço até final decisão do processo.

Essas garantias são específicas para assegurar ao trabalhador o direito de romper o contrato de trabalho sem ser culpabilizado. Porém, essas garantias não atende plenamente os casos de assédio moral. Deve-se, então, combiná-las com a proteção legal do CCB e da CF/1988.

Do ponto de vista penal, o assédio moral também pode e deve ser atacado. Apesar de não haver um tipo penal próprio para o assédio moral, a legislação existente atende plenamente à sociedade na inibição dos casos de abusos contra pessoa. O que e preciso ter em mente é o fato de a culpa estar bem demonstrada, pois a ação será contra pessoa(s). Sendo contra pessoa(s) o direito é igual para todos, logo o direito à liberdade vem antes de qualquer pressuposição. Assim, tanto o(s) agressor(es) quanto a(s) vítima(s) tem esse direito. No nosso ordenamento jurídico ainda não é possível penalizar a pessoa jurídica.

A ação penal deve ser intentada contra o(s) agressor(es) direto(s) e não contra a instituição ou organização. Nesse caso, toda e qualquer pessoa que se coloque como agente da atitude abusiva é passível de punição. A vítima não precisa ter receio de processá-los. Basta ter as provas.

Por isso, se o agressor sabe de alguma particularidade da saúde da vítima e, em razão desse conhecimento, já com a intenção de prejudicá-la, der azo à sua conduta abusiva e com isso venha causar-lhe dano físico ou psicológico, pode ser enquadrado em diversos artigos do CPB, pois são crimes, nas formas dos artigos discriminados em anexo. 
Em conclusão, o elenco de previsões legais de condutas abusivas aqui discriminados não é exaustivo, nem mesmo os direitos e proibições dos servidores públicos. Possivelmente haverá outras formas legais para o combate ao assédio moral, principalmente para situações especiais. Porém é uma amostragem do que se pode usar para se enfrentar as condutas abusivas no ambiente de trabalho.

Como já discutido, sendo o assediador, servidor público, o Estado (União, Estado Federado ou Município) pode ser responsabilizado pelos danos materiais e morais sofridos pela vítima, porque possui responsabilidade objetiva atribuída por lei (independe de prova de sua culpa). Comprovado o fato e o dano, cabe ao Estado indenizar a vítima, podendo, entretanto, processar o assediador, visando reparar os prejuízos que sofrer.

No caso da vítima, é essencial procure guardar provas, tais como: relatar os acontecimentos a um médico para que seja consignado no seu prontuário; ao sindicato da categoria, guardando consigo o protocolo da queixa, ou a um advogado particular.

Para que a queixa sejam exitosa, é preciso dar muita atenção às provas. Isso é importante tanto na Justiça quanto administrativamente.

Nesse sentido, Silva ${ }^{21}$, autor do livro Assédio Moral no Ambiente de Trabalho, em artigo publicado no site http://www.psicologia.org.br/internacional/pscl87.htm, acessado em 26/05/2010, enfatiza:

“No mundo jurídico o tema 'prova' é de essencial importância. Nada pode ser movimentado na Justiça, nada pode ser pleiteado em juízo, se o destinatário do direito não possuir o mínimo de aporte probatório necessário a comprovar o direito alegado.

$[\ldots]$

Assim, a vítima tão logo perceba o desenvolvimento de um processo de assédio moral, deverá catalogar todas as provas necessárias à demonstração futura de tal situação. Bilhetes, memorandos, anotações referentes a datas e eventos relacionados, testemunhas, gravações, laudos médicos etc.

Sempre é bom salientar que não há ilicitude algum em se gravar as ofensas, na hipótese de ser a vítima um dos elementos interlocutores. O que jamais

21 Jorge Luiz de Oliveira da Silva é Assessor Jurídico do Comando do Exército e Professor de Criminologia e Direito Processual Penal da Universidade Estácio de Sá. Mestre em Direito Público e Evolução Social (UNESA), Pós-Graduado em Direito Penal e Processual Penal (UNESA), Pós-Graduado em Docência Superior (ISEP) e Graduado em Ciência Jurídicas e Sociais pela UFRJ 
poderá ser considerado como prova ilícita, tendo inclusive o potencial para responsabilizar seus autores, é a gravação de conversa alheia, a interceptação telefônica ou o documento ou escrito conseguido de forma fraudulenta ou lesiva".

Além desses cuidados a vítima deve procurar ajuda junto aos órgãos competentes como o Ministério Público, a Justiça do Trabalho, a Comissão de Direitos Humanos e o Conselho Regional de Medicina. Provavelmente, a vítima que tiver ciência dos seus direitos e recorrer à Justiça será alvo de perseguições do assediador. Porém, ganha naquilo que é mais precioso ao ser humano: a dignidade e a preservação da sua vida, lutando sempre para não ficar intimidado diante da situação. 


\section{METODOLOGIA}

O tipo de pesquisa usada foi misto a (qualitativa e quantitativa) com perguntas abertas e fechadas com aplicação de questionários. O objetivo foi avaliar a existência do fenômeno assédio moral e as suas consequências na saúde física e psicológica do servidor da UnB.

Os questionários com dez perguntas abertas e fechadas e um pedido de relato de um caso de assédio moral (ver apêndice A na pág. 64) foram distribuídos no Campus da UnB, no período de 23 de março a 18 de abril de 2010. A amostra foi aleatória, sem escolha prévia para qualquer faixa etária, cargo, nível de escolaridade e gênero, num total de 36 respondentes. Alguns questionários foram enviados pela internet a pedido dos próprios respondentes, que solicitaram mais tempo para elaborar o relato. Outros foram aplicados pela própria pesquisadora.

O período da distribuição do questionário coincidiu com a greve dos servidores da $\mathrm{UnB}$, isso causou um certa dificuldade para localizar as pessoas.

Após o recolhimento dos questionários, já com as repostas e alternativas devidamente codificadas (ver apêndice B pág. 66) foi feita a tabulação dos dados com levantamento das freqüências absolutas e relativas (ver apêndice ).

$\mathrm{Na}$ tabulação visou-se, principalmente, apurar as freqüências relativas, isto é, quantos por cento dos 36 entrevistados responderam a cada pergunta e, especificamente, a cada alternativa ou alternativas.

A análise dos dados foi quase que totalmente qualitativa. No caso dos relatos, $52,78 \%$ contaram a sua história de vítima de assédio moral. As informações foram usadas para demonstração do que foi estudado no corpo da fundamentação, a fim de se confirmar as consequências na saúde física e psicológica dos servidores e os danos do fenômeno assédio moral como uma realidade do dia-a-dia nos diversos ambientes de trabalho da UnB.

Os relatos a seguir são casos verídicos que aonde os nomes dos respondentes foram preservados e substituídos por ouros fictícios para a preservação dos respondentes. 


\section{RELATOS ESPONTÂNEOS DE CASOS DE ASSÉDIO MORAL COLETADOS NA PESQUISA}

Neste item da monografia, são apresentados alguns casos reais que foram coletados na pesquisa, para servir de demonstração e comprovação do que foi estudado até o momento assédio moral. É uma realidade do dia-a-dia nos diversos ambientes de trabalho da UnB. Para isso foi feito o seguinte pedido no questionário (ver apêndice ):

Após ter respondido as perguntas e se você se considera que foi ou está sendo assediado moralmente, conte aqui a sua história. Não precisa usar o seu nome. As informações serão usadas exclusivamente para essa pesquisa.

Portanto, os nomes, nos relatos a seguir, são fictícios para proteger a pessoa do respondente. Os relatos estão transcritos de conformidade com os originais.

\subsection{Caso 1- Usurpação do trabalho, da criação e da competência do subordinado}

Marta:

"durante todos os domingos do ano de 2008, após ouvir a música que finaliza o 'Fantástico', programa da TV Globo, vinha àquela angústia, aquele calafrio no corpo. O coração palpitava e parecia querer romper o meu peito. Talvez fosse mais fácil morrer que ter de aceitar a idéia de ter que voltar ao trabalho no dia seguinte. Eu não queria mais que chegasse a segunda-feira e quando eu chegava no trabalho, logo começava a sentir tonturas, tremores, dores no corpo e me sentindo confusa. Essa confusão não me permitia fazer meu trabalho, mesmo porque as tarefas recebidas eram deliberadamente confusas.

Admitir que estivesse doente seria motivo para aumentar ainda mais o meu pânico.

A insônia era a minha fiel companheira de todos os dias. Os pensamentos desordenados e insistentes não davam trégua a minha mente. Noites inteiras sem descanso. Quando dormia, o sono era perturbado com pesadelos, calafrios e medo. Lembrava incessantemente dos maus tratos, da indiferença dos colegas, que fingiam não perceber o meu sofrimento, a minha humilhação, os abusos de poder, as injustiças e as ameaças frequentes que recebia da chefia. 
O ambiente ficou insuportável. Eu tinha crises frequentes de choro e era levada a miúdo ao hospital com alterações de pressão e estresse que sempre resultava em eu ter que me ausentar do trabalho.

O chefe tinha uma meta, um objetivo: estava ansioso para aparecer como muito competente diante da chefia superior, inclusive em habilidades que eram próprias e da competência dos subordinados. Como ele não sabia como dirigir o setor, usava dessa artimanha para mostrar produção ou algo relevante à chefia superior.

Mesmo não tendo conhecimento detalhado do meu serviço, ele se apoderava do trabalho que eu fazia, apresentando-o como seu. Até das criações artística que eu fazia, ele se apoderava, dizendo-se o autor. Promovia modificações nesses trabalhos sem fundamento técnicos, artísticos ou, mesmo, para atender necessidade do serviço. Contra essa usurpação e mutilações eu resistia, dizendo-lhe que o trabalho era meu e ele não devia, pessoalmente, modificá-lo ou dizer que ele foi quem o fez.

Percebendo ele essa resistência, partiu para me desestabilizar: interferindo na minha criatividade, e tentando convencer a todos que eu era incapaz tecnicamente para a realização das minhas tarefas. Usava a tática de apontar o menor descuido ou erro insignificante. Corrigia esse pequeno incidente e apresentava o resultado final como seu. Pedia um projeto artístico, mudava uma cor e dizia que o trabalho era seu. Pior, ainda, fazia propaganda dessa sua pseudocriação, dando a entender, no ambiente de trabalho, principalmente para a chefia superior, que eu nada fazia. Com isso esvaziar minhas funções e tirava a minha possibilidade de trabalhar.

Nesse desiderato, a perseguição ficou cada vez mais freqüente. O clima no setor de trabalho era de insegurança e pânico.

No final, minha capacidade de trabalho estava comprometida: não mais conseguia desenvolver o meu trabalho com tranquilidade e comecei a cometer enganos e a ter lapsos de memória, cominando em falta de criatividade e capacidade para tomar iniciativa. O gerente atingira o seu objetivo.

Sem ajuda, eu não sabia como sair da situação em que me encontrava. Sentia-me em meio a uma guerra e não tinha armas para combater essa batalha. Confusa, muitas vezes me achava culpada por essa situação. Depois de repetidos momentos de constrangimentos, penso que perdera a coragem e a capacidade para trabalhar e para tomar uma iniciativa.

Numa tentativa desesperada, fui pedir ajuda à chefia superior. Porém não me atentara para o que já era mais que sabido: a chefia superior tinha relações de favoritismo com esse meu chefe. Tentei, por algumas vezes, conversar com a chefia superior, querendo explicar o 
que estava acontecendo. Essa chefia mostrava-se indiferente aos meus reclamos. Mais ainda, porque os meus colegas de trabalho demonstravam insensibilidade ou indiferença para o que me ocorria. Apesar de alguns deles estarem passando pelos mesmos problemas. Não suportando mais tanta afronta fui orientada pela minha família para procurar um médico. Resolvi pedir ajuda aos profissionais da psicologia e da psiquiatria para entender o que estava acontecendo e consequentemente fazer um tratamento para poder dá continuidade à minha. Eu precisava ter certeza do que eu estava sentindo. O fato era que esse sentimento de inutilidade e medo, causava-me falta de confiança, gastrite, pressão alta, ansiedade, pânico e insônia.”

\subsection{Caso 2 - Assédio sexual de chefe (mulher) contra subordinado (homem)}

Miguel (testemunha dos fatos):

"Roberto um funcionário contratado pela UnB (terceirizado), era um senhor de meia idade, bonito, de boa aparência, separado, e tinha um filho de 10 anos de idade de quem detinha a guarda. Por isso ele precisava do trabalho.

Sua chefe, uma senhora de 56 anos, solteira, era uma pessoa de difícil relacionamento - prepotente, arrogante, autoritária e sarcástica - costumava chamar os subordinados por palavras depreciativas e jocosas ao invés do nome, usando apelidos ridículos ou com o sentido de ridicularização: 'zé', 'miolo curto', 'menina', 'loura', 'patricinha' etc. Ou quando se referia a si própria, dizia: 'Eu sou poderosa!', 'Não é por nada, não, mas eu sou boa no que faço!', etc.

A chefe demonstrava ter interesse sexual por Roberto. Ela o pressionava de todas as formas. Certo dia, ela fez um convite para um almoço especial, e ele, não aceitando, passou a ser perseguido sistematicamente e humilhado diante dos colegas de trabalho.

A tática da chefe era passar em frente à mesa do Roberto, frequentemente pronunciando frases intimidativas, depreciativas e jocosas, tais como: 'Inteligência é para poucos!'; 'Tem gente que é só a casca!'; 'Meu Deus! Se eu pudesse...!'; 'Tem gente que só tem tamanho!'; 'Não tem nada não..., 'um dia é da caça, outro é do caçador!'; etc. Quando não gritava frases soltas, ela cantava letras musicais explicitamente visando perturbar o Roberto, tais como a do cantor romântico Odair José, Eu vou tirar você desse lugar:

'Eu vou tirar você desse lugar

Eu vou levar você pra ficar comigo

E não me interessa o que os outros vão pensar ...' 
Disso eu sei porque a nossa sala era um corredor por onde ela fazia questão de passar a todo instante, ironicamente soltando essas frases depreciativas ou provocantes. Por isso, ficava claro que eram direcionadas a ele.

Ele, por sua vez, disfarçava, fazendo-se de desentendido, mas sempre procurou impedir a sequência dos fatos, levando ao conhecimento da chefia superior, que providência alguma tomava.

Logo a situação passou a ser uma verdadeira tortura! Ele começou a ficar irritado e sem ânimo. Roberto não cedeu aos caprichos e aos assédios de sua chefe. Por isso, a relação entre os dois tornou-se insuportável e passando para o nível de agressões verbais entre os dois. Em vista disso, a qualidade de seus trabalhos caíram. Ele perdeu a espontaneidade e a criatividade. Começou a faltar ao expediente, ou saía cedo e ficava muitas horas ausente.

Os colegas mais próximos percebiam aquela situação constrangedora, porém, ficavam impotentes, com receio de uma represália.

Num esforço final, Roberto decidiu, mais uma e definitiva vez, pedir ajuda à chefia superior, porém não recebeu apoio, e, pior, foi sumariamente despedido. Consequentemente o caso foi à Justiça. Alguns colegas foram intimados a testemunharem em favor do Roberto, por isso passamos a ouvir, no ambiente de trabalho, piadinhas do tipo: 'Agora sei quem são meus inimigos aqui dentro!'; 'Não há um mal que não traga um bem!'; 'Muitas cabeças vão rolar aqui dentro!', ditas pela chefe.

Desgraçadamente, Roberto escolheu a Justiça do Trabalho ao invés da Justiça Federal, e o seu caso foi arquivado por improcedência, uma razão de que ele não era servidor público concursado. Contudo, a consequência principal desse incidente foi que o grupo (os colegas de trabalho) ficou intimidado e passou a sofrer calado, já que não via nenhuma perspectiva de justiça naquele ambiente."

\subsection{Caso 3 - Servidora é afastada do setor de lotação sem explicação}

Tatiana:

"Eu sofri um assédio moral no meu setor de trabalho, vindo diretamente do Diretor. Fui expulsa do meu local de trabalho e colocada pra fora de lá, sem nenhum esclarecimento. Levei o caso até a Reitoria, e nada se resolveu, pelo contrário, fui chamada para retirar a queixa que havia feito à Comissão de Ética, a qual deu o caso como problemas particulares a serem resolvidos fora da UnB.

Tenho um problema de saúde considerado muito sério pela junta médica, o qual se agravou muito depois deste assédio, e até hoje faço tra- 
tamento particular. Gostaria de ter denunciado ao Ministério Publico o que eu vivenciei , mas como não obtive nenhum apoio, desisti."

\title{
5.4 Caso 4 - Servidora que adquiriu $\mathrm{LER}^{22}$ no trabalho é ridicularizada pela chefe
}

\author{
Cristina (colega de trabalho):
}

"Joana é funcionária pública com 40 anos de idade, educação de nível médio e trabalhou sempre na mesma função de digitadora, durante quinze anos, num dos órgãos complementares da UnB. Era insistentemente cobrada a produzir mais e sem observância do tempo de descanso necessário e previsto na legislação privada. A fadiga, o cansaço, as dores, a irritação sofrida, de nada serviram para sensibilizar sua chefe, e fazê-la perceber o mal a que a estava causando. Resultou que Joana veio a adquirir LER e DORT - lesões por esforços repetitivos e doenças osteomusculares relacionadas.

A chefe estava num daqueles cargos que 'possuem uma comissão extra' (sabe-se lá de onde a tiravam), e não se portava condizentemente como uma verdadeira chefe, pois só se dirigia à Joana com deboches e atitudes de humilhação. Joana entrou em um estado de total desânimo, com reflexos em sua saúde, na forma de náuseas, tonturas, medo e outros sintomas psicológicos consequentes.

Com o agravamento da doença, Joana passou a ter a necessidade de, cada vez mais, frequentar os consultórios médicos, e, consequentemente, se ausentar do trabalho. Contudo os exames diagnosticaram em Joana um quadro de síndrome do pânico e um distúrbio na tireóide. A situação ficou, então, insustentável, porque a chefe exigia mais produção independente de Joana estar impossibilitada de atendê-la. Só restou a Joana pedir para mudar de setor, pedido esse que não foi atendido. Não sendo atendida, Joana se dirigiu à chefia superior relatando as razões de seu pedido. De nada adiantou, pois a chefia superior apoiou a chefe de Joana, justificando, paradoxalmente, que ali era um local de trabalho e não um lugar para reclamações, nem tampouco para gente doente.

Depois de muita luta, hoje, Joana trabalha em outro setor da UnB, sem as reparações pelos danos sofridos."

22 A LER e DORT são as siglas para Lesões por Esforços Repetitivos e Distúrbios Osteo-musculares Relacionados ao Trabalho, sendo doenças caracterizadas pelo desgaste de estruturas do sistema músculo-esquelético que atingem várias categorias profissionais. http://www.bancodesaude.com.br/ler-dort/ler-dort . 


\subsection{Caso 5 - O Chefe imputava à sua auxiliar imediata os danos que ele mesmo causava}

Maria:

"Trabalhei durante dois anos num setor hospitalar da UnB. Nos procedimentos cirúrgicos eram utilizado vários equipamentos caros. Alguns eram reesterilizados e utilizados novamente. Quando um desses equipamentos quebravam ou apareciam com algum defeito, o cirurgião chefe afirmava que eu havia danificado os produtos. Tais acusações geralmente eram feitas perante anestesistas e o paciente. Ele falava de uma forma que eu me sentia inibida de me defender.

Por várias vezes comentei com a chefia imediata o que estava acontecendo e ela me falava que ele era assim mesmo, e que eu deveria ter paciência, pois no momento da cirurgia é normal o médico ficar ansioso e nervoso. Todas as terças e quintas-feiras, eu trabalhava com esse mesmo médico, e as acusações continuavam. Como não tinha auxílio de ninguém, comecei a chamar algumas colegas para mostrar o estado do equipamento no início e fim de cirurgia. Se quebrava alguma "alça” já escrevia no relatório de enfermagem. Mesmo assim, as acusações continuavam, onde ele afirmava que eu tinha mais de 10 anos de enfermagem e não aprendia o serviço!!! Solicitei várias vezes para a enfermeira chefe não me colocar para trabalhar com o médico acima citado, pois eu estava muito estressada e cansada de tanta reclamação. Ela falava que não tinha ninguém que soubesse executar o serviço, e só eu podia fazê-lo. Fui parar no psiquiatra, onde foi diagnosticado síndrome do pânico, e depois de muito diálogo com a psiquiatra, ela perguntou se havia a possibilidade de transferência de setor ou até deixar de trabalhar com o médico.

Atualmente continuo no mesmo setor, porém não trabalho com o mesmo médico. Ele ficou sabendo de toda a história. A nova chefia colocou duas auxiliares de enfermagem para ficar com ele na sala. E que se ele continuasse reclamando e acusando sem motivos elas não trabalhariam mais com ele.

Só no ano de 2009, onde o setor estava buscando a acreditação, ou seja o certificado de qualidade total, fiquei sabendo que o material utilizado nas cirurgias era de uso único, e, segundo o controle de infecção hospitalar, não poderiam ser reesterilizados e utilizados novamente." 
Caso 6 - Servidora que se achava "a maior pensadora do mundo" tenta desqualificar demais colegas no ambiente de trabalho

Matias:

"Uma professora que se acha a maior pensadora do mundo há anos vem procurando, por meio de palavras e atos, desqualificar todos no ambiente de trabalho, até que eu, na condição de chefe de departamento procurei impedir isso, e a ira dessa mulher se voltou contra mim, por meios indiretos, $\{\mathrm{com}\}$ comentários maldosos entre os alunos, os quais repercutiam no departamento, como também em infindáveis discussões inúteis durante colegiados e reuniões. O nível de tensão chegou ao extremo quando a figura explodiu aos berros em uma reunião contra minha pessoa. Minha pressão arterial se modificou naquela semana, fiz exames e constatou-se que não passava de estresse \{em razão\} da situação que se acumulara. Desde essa época resolvi não mais dirigir a palavra para essa pessoa."

\subsection{Caso 7 - Servidor constrangido moralmente não pode processar o agressor em razão do medo de represálias contra as testemunhas}

José:

"Sofri assédio moral e, na época, não denunciei, pois não tinha apoio dos colegas mais próximos, e tive receio de arrolá-los no processo, e passar por constrangimento, uma vez que a maioria deles era prestador de serviço. Tinham receio de serem demitidos. Cheguei a procurar o Sindicato, mas continuei com receio, pois a condição de apresentar testemunhas era indispensável no processo. Além disso, o agressor tinha respaldo da Administração Superior; outras pessoas já haviam passado pela mesma situação e nada acontecera com o agressor. Era a política do opressor X oprimido. Tive prejuízo financeiro, moral e psicológico. Tentei nova colocação no âmbito da Instituição, e eu era visto como o 'bandido' da história. O longo tempo de serviço e o grande ciclo de amigos que formei na Instituição constituíram fatores negativos nesse momento turbulento da minha vida profissional e pessoal e, por pouco, não abalou minha vida afetiva. O meu psicológico ficou muito abalado, e pensamentos negativos, de vingança e ódio, passavam pela minha cabeça frequentemente. Entretanto, tive novo desafio na Instituição, na área de Recursos Humanos, onde fiquei por seis meses e, em seguida, deixei a Instituição para assumir novo desafio numa área completamente diferente das que já havia trabalhado antes. Estou muito bem hoje, em todos os aspectos: profissional, afetivo, pessoal, social, financeiro, acadêmico. Ah, o agressor? Bem, há tempos não tenho notícias 
dele, mas sei que está respondendo a processos de improbidade administrativa, peculato, desvio de recursos... Certamente estou em melhores condições que ele!

\subsection{Caso 8 - Servidora, sem motivo justificado, foi impedida de ter acesso aos documen- tos necessários ao seu trabalho}

Márcia:

“Trabalhei por 10 anos num setor, praticamente só, cuidando de toda a documentação específica da área. Não apenas cuidando, mas organizando e zelando por todos os assuntos com os quais trabalhava diariamente. Com a mudança da chefia do setor e devido a uma reviravolta na Universidade, fiquei impedida de ter acesso a esses documentos para realização do trabalho, tendo que fazê-lo praticamente na frente do novo chefe - que por sua vez, acabou sendo demitido meses depois (era terceirizado) por total incompetência para o cargo. Fora isso, esse chefe já se dirigia a mim (e não apenas a mim) com agressividade, ironia, deboche e provocação, como se pretendesse mesmo provocar e descontrolar o servidor para que ele saísse de lá. O diretor do setor também novo - respaldava toda e qualquer atitude desse chefe, pois tinha o mesmo comportamento. Ambos, e outros da equipe, criaram uma situação caótica no setor, pois não souberam respeitar os servidores da área. Saí de lá há dois anos, revoltada e totalmente sem entusiasmo para dedicar-me ao trabalho como antes. A administração superior da Universidade comporta-se de forma desrespeitosa para com o profissional técnico-administrativo. Para quem trabalha com responsabilidade, dedicação, cumprimento de horário, disposição, honestidade, por anos a fio, uma situação dessa é humilhante e desgastante, lamentável."

\subsection{Caso 9 - Estagiário é removido do setor de trabalho sem motivo justo}

Raul:

"Eu era servidor de um setor da UnB, que sofreu a troca de chefia. A nova chefia entrou no setor e simplesmente começou a tirar do setor todos os servidores (maioria estagiários e terceirizados) sem motivos claros e nitidamente por questão pessoal. Eu fui o último deles e o que mais deu trabalho, pois não fiquei calado. Ela queria me tirar não somente do local de trabalho como da UnB.

Não conformado com isso, fiz uma carta destinada à SRH, informando tudo o que aconteceu com todos (com a permissão dos envolvidos 
para serem citados), e a SRH 'apenas' me trocou de setor, pois disse que as reclamações de quem estava pedindo o encerramento de contrato não procediam, uma vez que eram contrárias a todas as minhas avaliações de estágio anteriores a chegada da mesma no local em que eu trabalhava."

\subsection{Caso 10 - Servidora sofre por perseguição religiosa}

Rita:

"Na época foi muito difícil pra mim, pois sofri muito a ponto de jogar tudo para o alto mais perseverei e resisti até o fim. Acho que por minha religião o meu chefe me perseguia tanto. Teve momentos de não querer ir trabalhar e só querer sair correndo pra bem longe. Eu só conseguia chorar, mas meu desempenho na instituição não foi comprometido, acho porque semre fui apaixonada pelo que faço.

Hoje ele não é mais o meu chefe, mas temos uma boa relação apesar de não vê-lo a muito tempo."

\subsection{Caso 11 - Servidora sofre difamações dinates dos colegas}

Fabiana:

"Trabalhei alguns anos, em um departamento da UnB nos primeiros anos foi tudo muito bem, mas depois de um certo tempo, chegou um novo secretário para a secretaria do departamento foi aí que começou meu sofrimento, fui nomeada para trabalhar no instituto do depto como secretaria do Instituto nesse período acabou a gratificação para secretario de depto e o secretário começou a me atormentar com piadas e tudo que fazia colocava defeito me difamando perante os professores.

Uma das vezes no meio de uma reunião de departamento gritou comigo no meio do corredor usando Palavras de baixo escalão. Pois achava que a gratificação ora oferecida para mim, pela Direção do Dpto teria tirado dele. Então a meu pedido fui exonerada da Função de secretária e ao mesmo tempo fiz um memorando Pedindo para sair do Dpto, pois ali não me sentia mais bem. Por algum tempo fiquei me sentido insegura, me isolando das pessoas no ambiente de trabalho." 


\subsection{Caso 12 - Servidora sofre exclusão}

Marlene:

"Sofri o assédio de exclusão, descaso, imagem exposta ao público."

\subsection{Caso 13 - Servidora sofria constantes constragimentos}

Zelma:

"Acredito que por ser do sexo feminino e conviver num ambiente dominado por homens, tenha sofrido Assédio moral. Na verdade nem imaginava se tratar desse assunto. Apesar dos vários e constantes constrangimentos, superei essa fase difícil. Aprendi a confiar mais na minha capacidade e isso foi positivo.

Não guardo nenhum tipo de mágoa ou ressentimento.”

\subsection{Caso 14 - Servidora sofria constantes humilhações e discrimações}

\section{Cristina:}

"Eu fui discriminada com afirmativas de que eu era muito competente, fazia tudo rápido e bem feito.

Senti-me muito mal por ter de me fazer de BURRA para ser aceita, e, muitas vezes, fiz, pois sou a chefe da casa e sustento minha casa.

Também fui discriminada sexualmente, com frase do tipo: "Não gosto de trabalhar com mulher inteligente."

Ou elogios idiotas: "vocês estava com um vestido lindo ontem", partindo de um homem, quando eu falava de um tema de trabalho.

O Reitor xxxxx me colocou para segurar a mala de documentos dele, para mostrar que ele era o chefe,

Isso aconteceu no RJ no Centro Nacional de Física, e eu sou Física, e disse isso a ele, e carregar a mala dele era uma forma de me inferiorizar, mas só ficou um grande com aquela atitude.

O Reitor xxxxxxx, quando vice-reitor, disse de forma direta "Não queremos você na equipe", era um projeto que eu criei e negociei por um ano e meio com uma escola de gastronomia das mais bem reconhecidas no mundo - Le Cordon Blue. E colocou no meu lugar uma funcionária aposentada do MEC, a quem ele devia favores.

Tenho outros relatos, mas, em minha opinião, a maioria dos professores da UnB, com seus doutorados em Paris VI ou outro lugar qualquer, continua como uns seres bem atrasados. 
Eles, na sua grande maioria, percebem que estão apenas cumprindo a lei quando deixam os funcionários estudarem. Mas não reconhecem e nem valorizam.

Agora, sem brincadeira, não ligo mais, sei que sou uma mulher capaz, inteligente e bonita, com dois filhos maravilhosos. A opinião deles é apenas deles. Já tenho a minha sobre mim mesma.

Não entro em atrito com eles, não sou responsável pela evolução de dinossauros, com $\mathrm{PhD}$, com todo respeito aos dinossauros." 


\section{ANÁLISE DAS RESPOSTAS}

Dos 36 questionários distribuídos, cem por cento foram respondidos. Como o objetivo desta monografia é identificar, por meio de pesquisa, a prática de assédio moral no ambiente de trabalho do servidor da UnB e quais as consequências para a saúde física e psicológica das pessoas, a primeira pergunta teria que ser obrigatoriamente esta: $\mathrm{n}^{\circ} 1$ - Você diria que já foi ou é vítima de assédio moral?

Foram obtidos 72,22\% de SIM e 27,78\% de NÃO. Esse resultado leva a concluir que há assédio moral no âmbito da UnB, pois percebe-se que os dados apontam para mais de dois terços dos entrevistados que sofreram assédio moral no exercício de seu trabalho na Instituição.

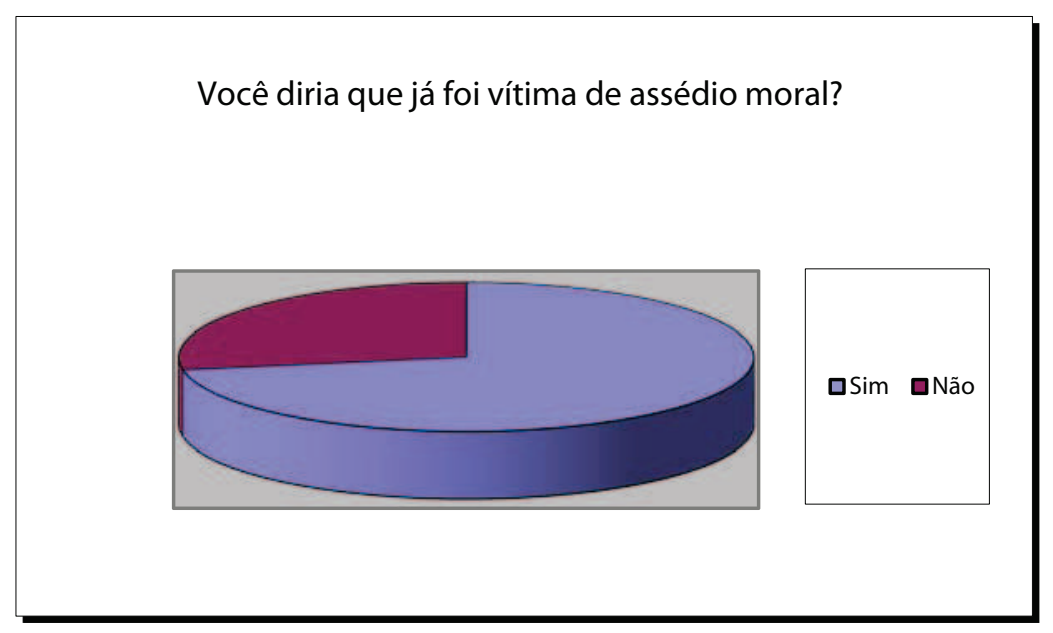

Figura 1. Distribuição dos 100\% dos respondentes entre SIM e NÃO 
Como esta pesquisa visa descobrir vítimas de assédio moral, a pergunta $n^{\circ} 1$, naturalmente, tem um complemento: - Caso afirmativo, em que época ocorreu o assédio?

Somente $30,56 \%$ dos entrevistados informaram o período. Desses, $45 \%$ apontaram como maior ocorrência de assédio moral o ano de 2008. Esse foi um ano de protesto com a indignação dos estudantes e de suas famílias. A UnB estava atravessando uma crise ética. O ambiente de trabalho estava tenso. Há muito estava acontecendo condutas políticas nada compatíveis com a proposta da Universidade. A descontentação estava presente na maioria dos alunos e servidores. As pessoas estavam em busca de uma mudança na política

O alvo do protesto dos alunos eram desvios de finalidade na aplicação de recursos da instituição e da fundação de empreendimentos científicos e tecnológicos da universidade, originalmente destinados à pesquisa científica, e que foram aplicados indevidamente. Tudo cuminou com um grupo de 150 estudantes que ocupara a reitoria da UnB no dia 3 de abril exigindo a renúncia do reitor.

Os demais casos de assédio moral foram entre os anos de 1990 a 2009, sem grande concentração em algum ano. (55\%).

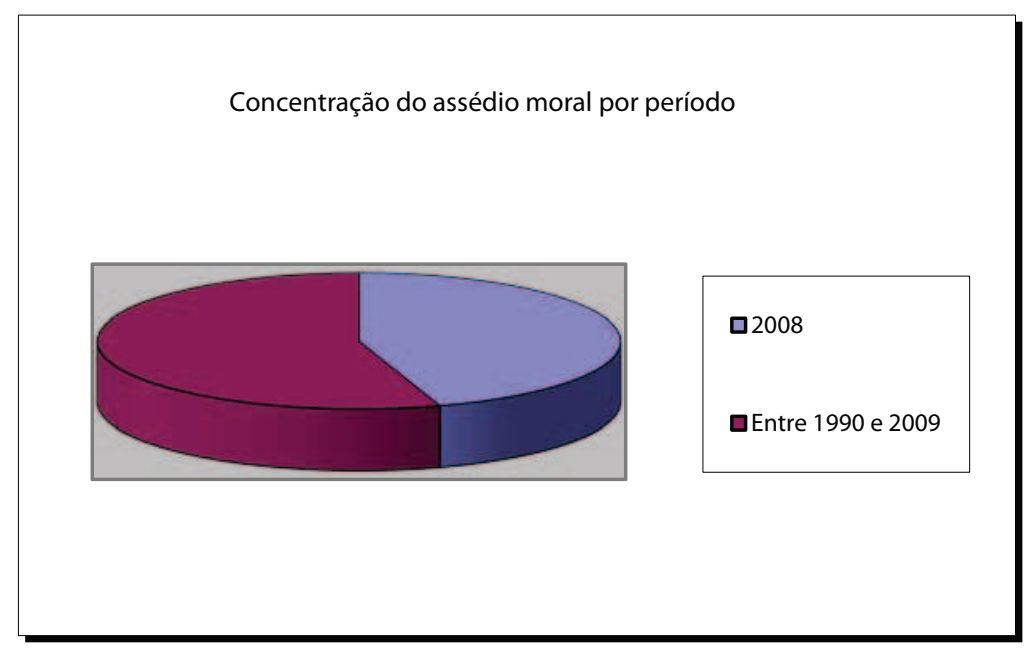

Figura 1a. Distribuição dos 30,56\% dos respondentes entre os períodos apontados em que ocorreu o fato 
Uma vez identificada a existência de assédio moral no âmbito da UnB, a questão de $\mathrm{n}^{\circ} 2$ - Ainda, se você respondeu SIM, qual o sexo do agressor?

A ela responderam $66,67 \%$ dos entrevistados, percentual distribuído em: $41,67 \%$ do sexo masculino e $25,00 \%$ do sexo feminino.

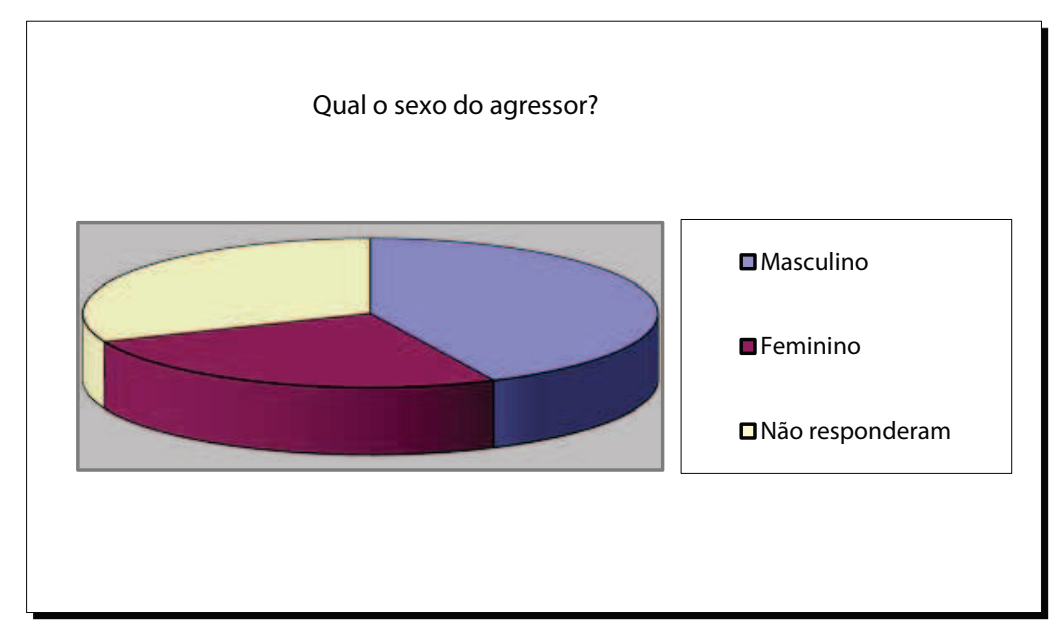

Figura 2. Distribuição dos $66,67 \%$ dos respondentes em cada sexo

Os dados e a figura 2 demonstram existir um forte indício que o gênero masculino é o principal agressor.

Destaca-se o fato de que 30,33\% preferiram não apontar o sexo do agressor. Isso é significativo porque é quase um terço dos entrevistados. Pode-se presumir que as vítimas ainda sentem "um certo" medo de identificar o agressor. 
O receio de apontar o agressor se confirma ainda mais porque $27,78 \%$ deixaram de responder a questão $\mathrm{n}^{\circ} .3$ - Qual a sua relação de trabalho com o agressor?

Porém 72,22\% dos entrevistados responderam. Esses dados foram assim distribuídos: $36,11 \%$ se referem ao Chefe; $27,78 \%$ ao Subordinado e $22,22 \%$ a Colega.

Observou-se que alguns dos entrevistados sofreram assédio moral por mais de um tipo de categoria, logo a soma dos percentuais dessas categorias ultrapassam os 72,78\%. Porém, para efeito de visualização, somente serão considerados os percentuais das categorias (figura 3).

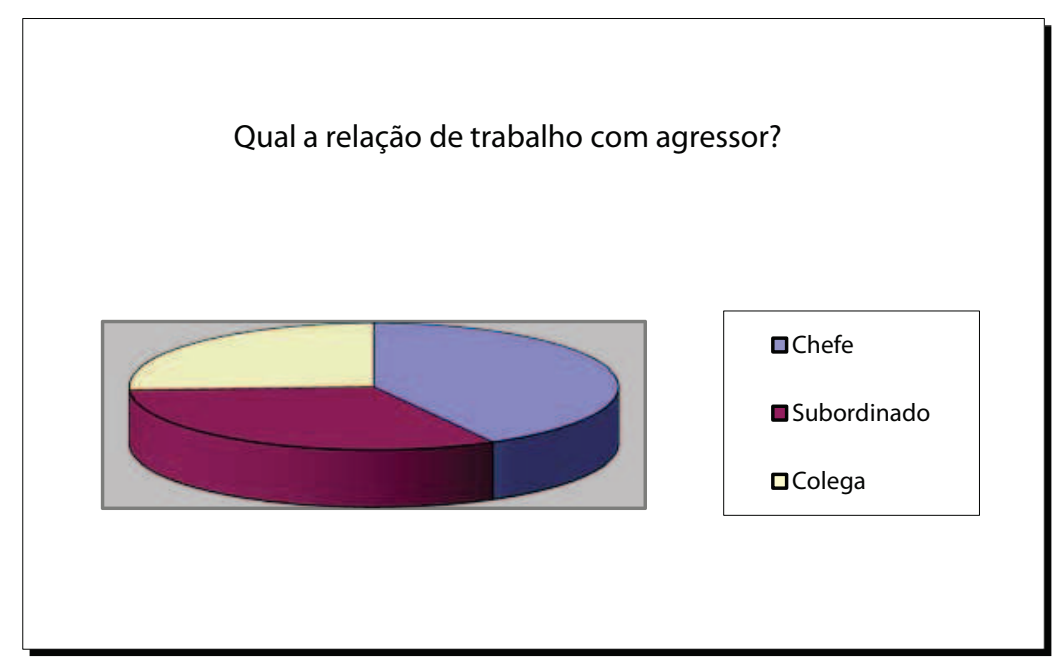

Figura 3. Distribuição dos respondentes nos tipos de ralações com agressor

Apesar de se esperar que o chefe seja o maior agente agressor, observa-se que as diferenças não são tão relevantes entre as categorias. 
Constatada a existência de assédio moral no âmbito da UnB, é preciso avaliar se o entrevistado sofreu algum dano. Essa informação foi pesquisada com a questão no .4 - Você sofreu ou sofre algum prejuizo em decorrência do assédio moral?

Enfrentaram a questão 77,78\% dos entrevistados, distribuídos em: 61,11\% com respostas positivas e 19,44\% disseram não ter sofrido dano com assédio.

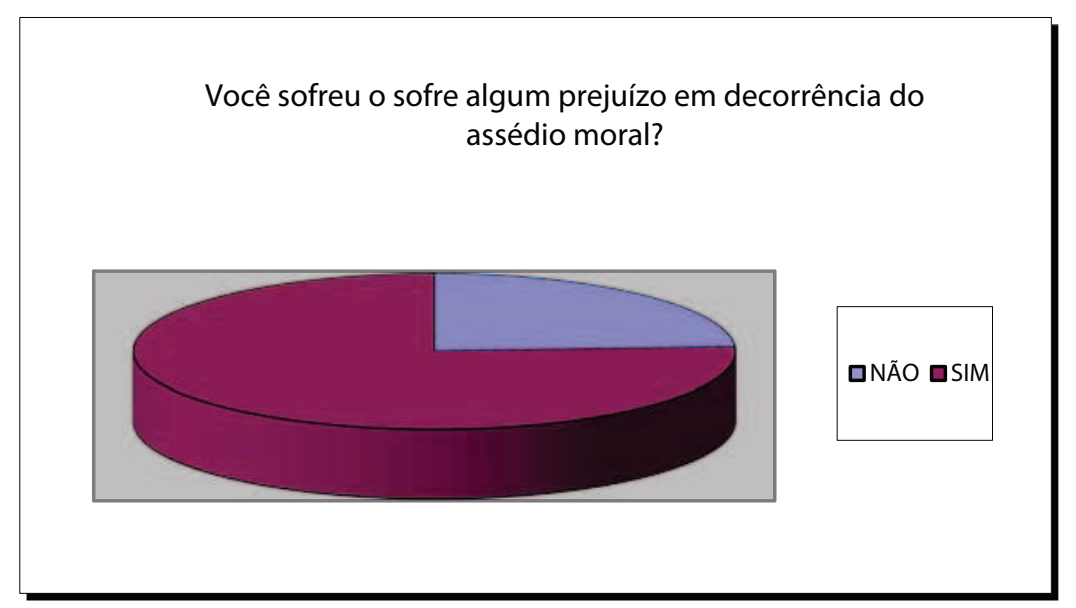

Figura 4. Distribuição dos 77,78\% dos respondentes em SIM e NÃO

Mais de dois terços dos entrevistados afirmaram que já sofreram assédio moral no ambiente de trabalho da Instituição (Figura 4). 
Aqueles que responderam positivamente ao questionamento ficaram assim divididos quanto aos danos: físico 13,89\%; psicológico 52,78\%; financeiro 11,11\%; e envolvimento com a Justiça 13,89\%.

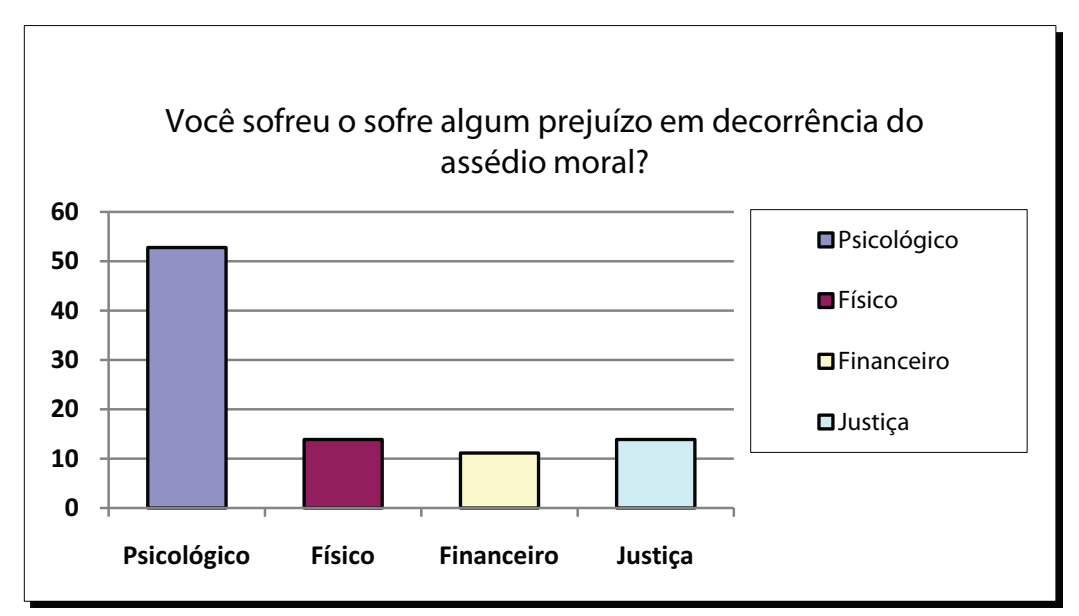

Figura 4a. Distribuição dos 61,11\% dos respondentes de SIM no tipo de dano sofrido

É um número muito significativo, mesmo considerando a pequena amostragem escolhida. A soma das percentagens alcança um total acima de 100\%. Esse resultado é consequência do fato de algumas pessoas haverem sofrido mais de um tipo de prejuízo causado pelo dano. Dentre os males causados pelo assédio moral, destaca-se o dano psicológico - o que mais afetou as vítimas de assédio moral - que obteve um total de 52,78\%. 
Procurando identificar se alguma espécie de doença foi causa de assédio moral, 97,22\% dos entrevistados responderam à questão no 5 - Você é portador de alguma doença? Observou-se que só $16,67 \%$ eram portadores de algum tipo de doença. A imensa maioria $80,56 \%$, se julgava bem de saúde.

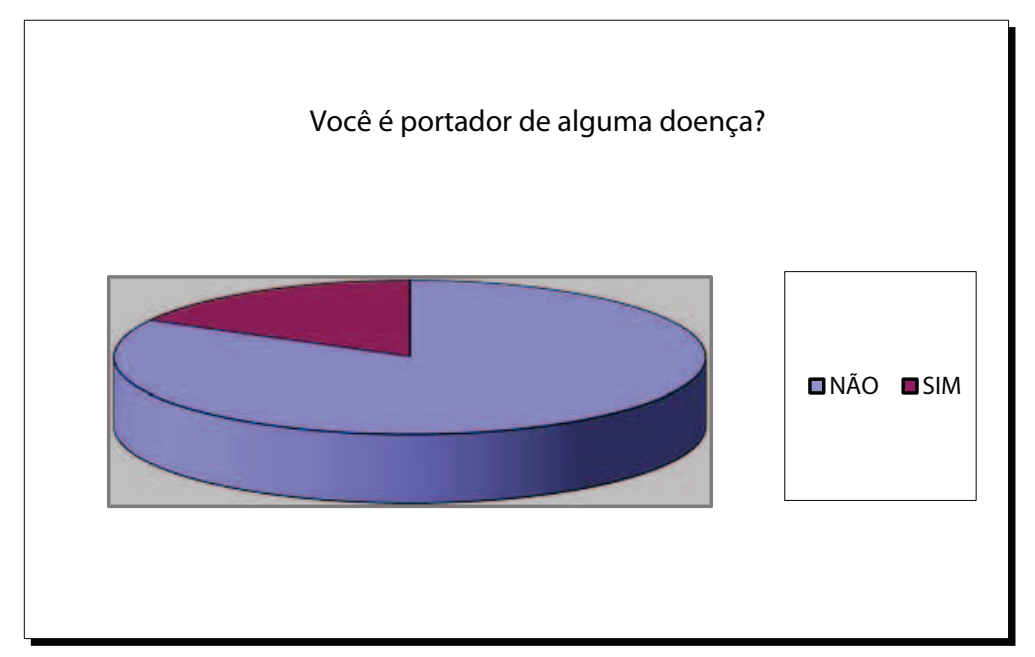

Figura 5. Distribuição dos 97,22\% dos respondentes entre os quem tem (SIM) e os que NÃO tem algum tipo de doença

Apesar de ser uma minoria que é portadora de alguma doença (Figura 5), será que esse fato influenciou na discriminação? O complemento da pergunta $\mathrm{n}^{\circ} .5$ esclarece: - Se afirmativa a resposta, você foi ou é discriminado por causa dessa doença?

Assim, dos 16,67\% que eram portadores de algum tipo de doença, a maior parte, $11,11 \%$, não se sentiu discriminada. Não obstante, 5,6\% sofreram assédio moral por motivo de sua doença. Observa-se que, mesmo sendo essa uma pequena porcentagem, não deixa de ser expressiva a existência de discriminação das vítimas portadoras de algum tipo de doença e que sofrem assédio moral, pois são protegidas por lei. 
De acordo com as respostas dos entrevistados, infere-se que existe assédio moral no espaço da UnB. Há que se avaliar, então, o grau de conhecimento dos entrevistados quanto à questão do assédio moral. Isso foi feito com a pergunta $\mathrm{n}^{\circ} .6$ - Você conhece na UnB alguma forma de divulgação sobre o que é assédio moral?

Responderam a questão 94,44\% dos entrevistados, sendo que $36,11 \%$ disseram conhecer alguma forma de divulgação sobre assédio moral na UnB, e 58,33\% desconhecem qualquer forma de processo de divulgação sobre esse tema.

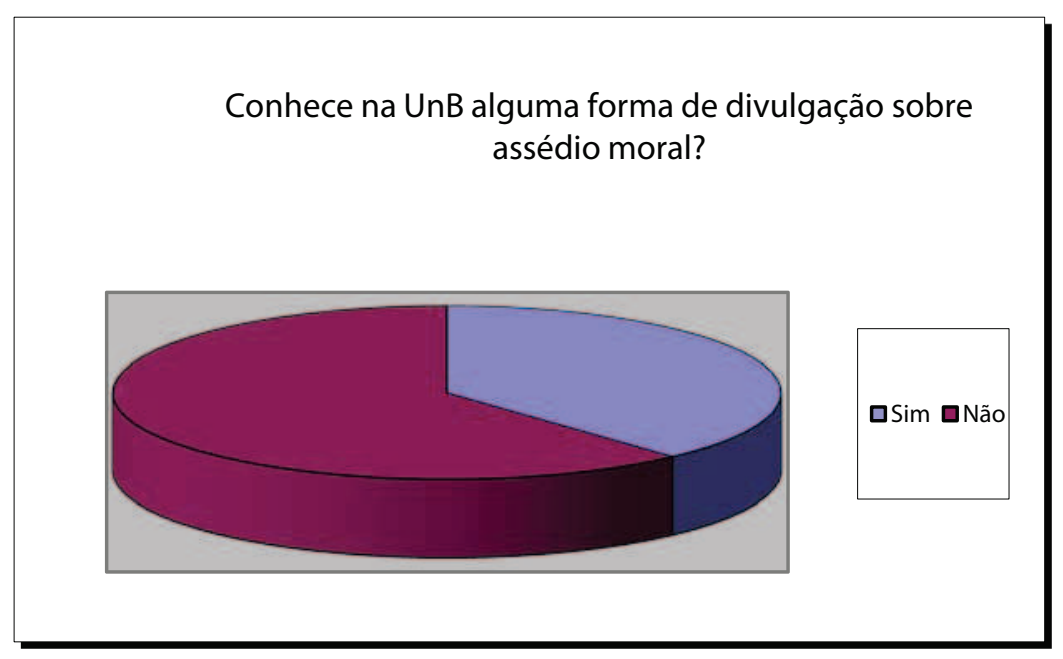

Figura 6. Distribuição dos $94,44 \%$ dos responderam SIM e NÃO

Pelas respostas, observa-se que mais da metade dos respondentes não conhecem nenhum tipo de divulgação do tema na UnB. Fica evidente que os dirigentes da UnB devem se conscientizar do problema e planejar uma política de divulgação sobre o assédio moral a fim de limitar as possíveis ocorrências do fato danoso, garantido um ambiente de trabalho mais sadio. 
Até agora os dados indicam que há assédio moral na UnB. Os pacientes desses possíveis assédios surgem de diversas formas de relações de trabalho praticadas na UnB. Procurou-se, então, descobrir o tipo de vínculo de trabalho dos entrevistados com a instituição fazendo a questão $\mathrm{n}^{\circ} .7$ - Qual o seu vínculo com a UnB?

A ela responderam 94,44\% dos entrevistados, assim distribuídos: professor, $11,11 \%$; aluno, nenhum; técnico administrativo, $63,89 \%$; e outro, $16,67 \%$.

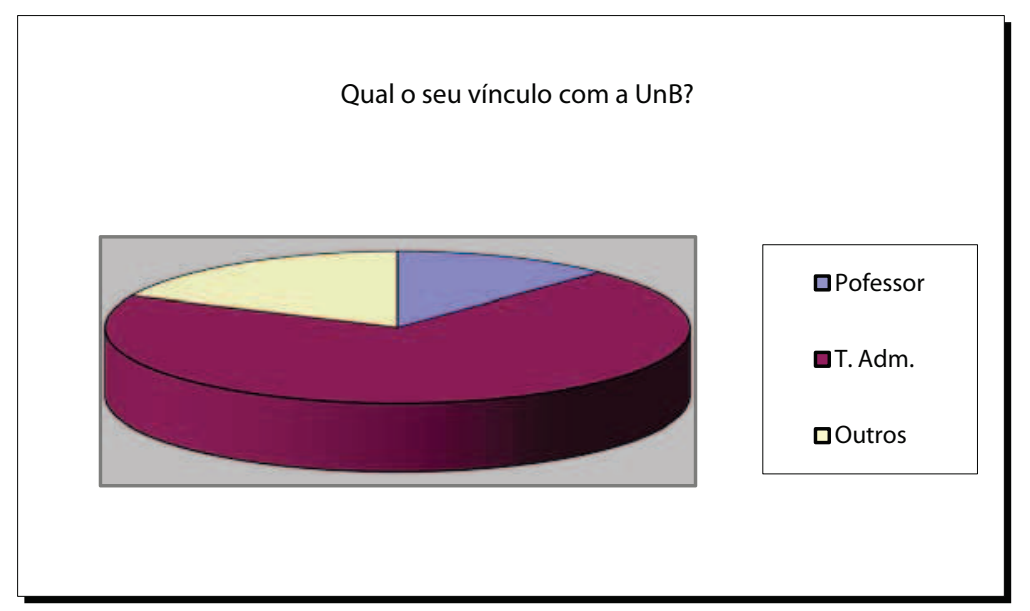

Figura 7. Distribuição dos 94,44\% dos respondentes entre Professores, T. Administrativos e Outros

Ainda, no complemento da pergunta no. 7 - Se outro, qual? - Evidenciou-se que os prestadores de serviços destacaram-se como a maioria: $83,33 \%$ daqueles $16,67 \%$.

Por outro lado, 63,89\% dos entrevistados são do corpo técnico administrativo da UnB. Infere-se, então, salvo outras explicações que a pesquisa desconhece que esse é um grupo mais interessado no assunto. 
Procurou-se descobrir o grau de informação (cultura formal) geral dos entrevistados pela questão $\mathrm{n}^{\circ} .8$ - Qual a sua escolaridade?

Responderam 94,44\% dos entrevistados. Todos tinham mais que a educação básica. Dos respondentes, 5,56\% tinham a escolaridade fundamental; 75\% possuíam a superior e $22,22 \%$ responderam "Outro". Na pergunta complementar que se seguiu a “Outro", i.e. "Qual" - a imensa maioria era de pós-graduados.

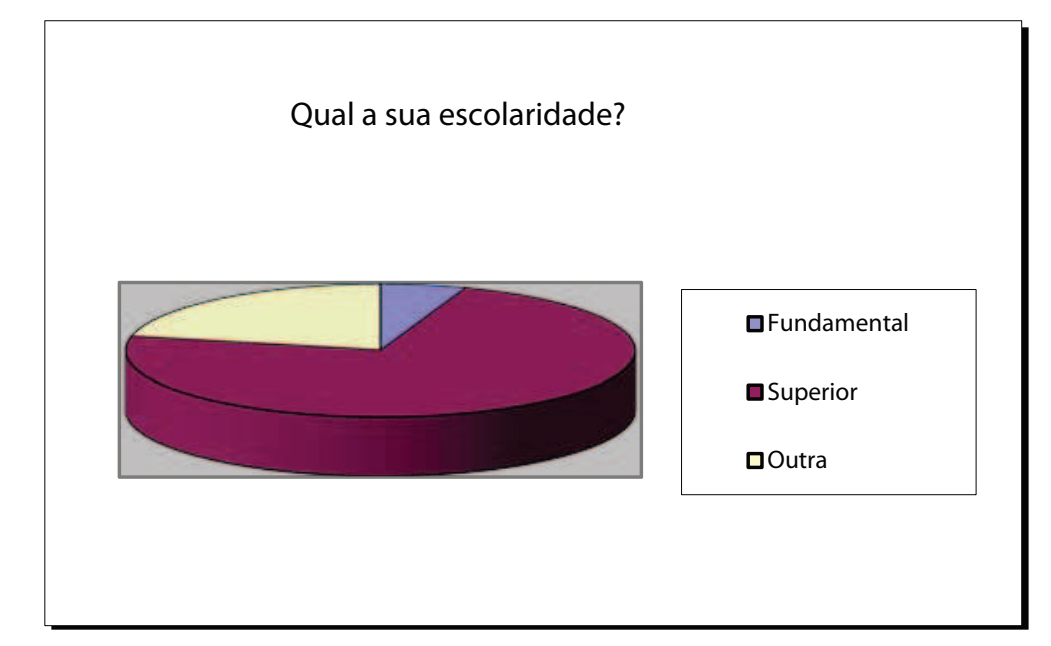

Figura 8. Distribuição dos $94,44 \%$ dos respondentes quanto ao tipo de educação

Destaca-se que 75\% dos entrevistados tem educação superior - mais de dois terços! Observou-se também que o quesito "Outro" recebeu 22,22\% das respostas. Porém, na realidade, esses entrevistados são todos pós-graduados dispersos em especialistas e doutores. 
Haveria que se saber o sexo dos entrevistados. Isso foi respondido pela questão de no. 9 - A que gênero você pertence?

Todos entrevistados (36) responderam. O sexo masculino participou com $36,11 \%$ e o feminino com $63,89 \%$.

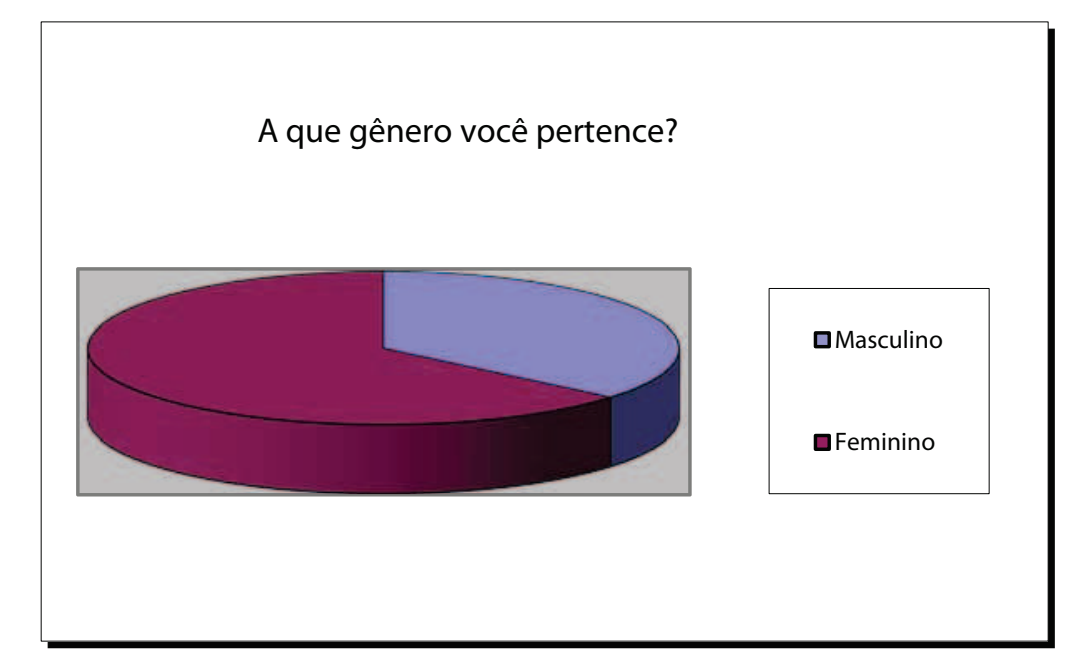

Figura 9. Distribuição de $100 \%$ dos respondentes entre o sexo feminino e o masculino

O que fica evidenciado é o crescente aumento de mulheres nos empregos públicos. E a UnB demonstra não estar fora desse perfil. 
Para se completar o perfil dos entrevistados, a idade foi buscada pela questão de $\mathrm{n}^{\circ} .10$ - Qual a sua faixa etária?

Responderam 94,44\% dos entrevistados. Desse total, $8,33 \%$ estavam na faixa dos 20 a 30 anos; $16,67 \%$ na dos 31 a $41 ; 55,56 \%$ na dos 42 a 52; $11,11 \%$ na dos 53 a 63 ; e $2,78 \%$ na faixa etária de mais idade.

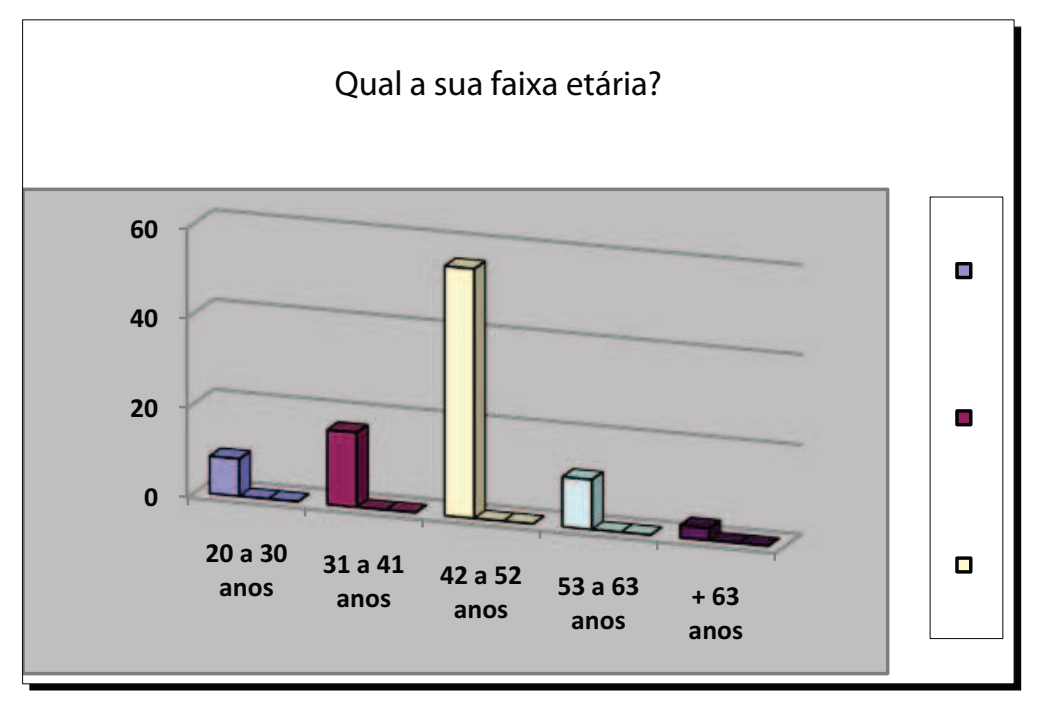

Figura 10. Distribuição de $94 \%$ respondentes entre as faixas etárias

Os dados indicam que mais da metade dos entrevistados estavam na faixa etária dos 42 a 52 anos. Os demais entrevistados distribuíram-se em outras faixas. 
Finalmente, testou-se a disposição dos entrevistados em relatar casos de assédio moral por eles sofridos. Foi proposto o pedido na forma do quesito $\mathrm{n}^{\circ} .11$ - Após ter respondido as perguntas e, se você se considera que foi ou está sendo assediado moralmente, conte aqui a sua história.

Atenderam à proposta em relatar casos de assédio moral por eles sofridos, 52,78\% dos entrevistados.

Se você foi ou está sendo assediado moralmente? Relate o fato

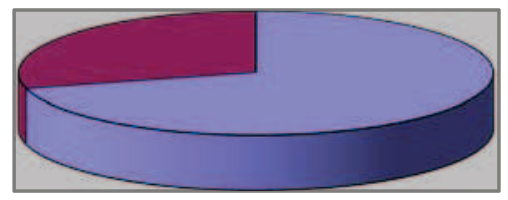

口Relataram

口Não Relataram

Figura 11. Dos 72,22\% que se declararam assediados na questão ${ }^{\circ} .1$-> c; $19,44 \%$ não relataram

Mais da metade dos entrevistados ousaram relatar o(s) fato(s) de que foram ou estão sendo vítimas. Contudo, outros 19,44\% (dentro dos $72,22 \%$ da amostra) mesmo que tenham sido ou ainda estejam sendo vítima de assédio moral preferiram não falar sobre o(s) caso(s). Isso evidencia que ainda existe medo de represálias do assediador.

No transcorrer desta monografia foi visto o que é assédio moral, suas diversas formas de manifestações e, principalmente, suas consequências para a saúde do servidor. Observou-se, com os dados colhidos, que o dano psicológico é o mais evidente, pois atinge a mais de dois terços dos entrevistados.

Com relação ao gênero, os dados apontam o sexo masculino como o maior assediador, contudo já não é a maioria esmagadora.

Constatou-se, também, que mais da metade dos entrevistados não tem conhecimento de qualquer divulgação institucional para esclarecer sobre assédio moral. 


\section{CONCLUSÃO E RECOMENDAÇÕES}

O assédio moral no ambiente de trabalho da UnB tem degradado as relações de trabalho e causado diversos tipos de transtornos para o servidor.

Dos casos relatados na pesquisa, é penoso saber que várias pessoas sofreram as consequências do assédio moral e que algumas sofreram mais de um tipo de dano, sem que providência alguma fosse tomada.

É muito preocupante que as pessoas esclarecidas ainda aceitem esse tipo de violência, permitindo a violação dos seus direitos essenciais à vida, à dignidade, à integridade física e moral, à intimidade, e, de um modo geral, à saúde.

O momento é de reflexão! Até quando o silêncio vai continuar sendo sufocado, suprimido pelo medo de represálias? Até quando a violência implícita nas relações de trabalho continuará existindo sem que haja alguma punição para aqueles que causam aos outros problemas de diversas ordens? É mais que sabido que o dano físico pode deixar marcas no ser humano, porém é certeza que o dano psicológico deixa marcas gravíssimas. O assédio moral destrói a autoestima, gera desilusão e corrói a alma.

Confrontando a realidade, o mais importante é identificar esse mal e a sua ocorrência no ambiente de trabalho, para que sejam punidos àqueles que fazem uso do assédio moral, levando-os à responsabilidade administrativa, civil e penal, com a reparação dos danos morais causados às vítimas.

Então, é importante que os profissionais de $\mathrm{RH}$ fiquem alertas para essa realidade, implementando políticas de boas maneiras nas relações de trabalho, promovendo a divulgação, a realização de fóruns e de palestras sobre o que é assédio moral, com o objetivo de deixar claro a não permissão desse tipo de comportamento perverso na UnB.

Não podemos ficar omissos diante da violência, do sofrimento, da humilhação, da tortura psicológica que afetam a alegria de viver do ser humano em toda a sua plenitude. $\mathrm{O}$ caminho é o limite nas hostilidades e a restrição dos meios e métodos que causem transtornos supérfluos ou sofrimentos desnecessários no ambiente de trabalho. 
É importante reconhecer as características da personalidade do agressor, principalmente identificar se suas atitudes sádicas, ameaçadoras, violentas e agressivas são repetitivas e constantes. Este é o assédio moral.

Diante da realidade do que foi apurado na pesquisa, fica a sugestão para que seja criada uma comissão paritária, com o objetivo de analisar e julgar casos de assédio moral dentro da UnB. Esse grupo seria formado por representantes das entidades envolvidas com a Instituição: professores, técnicos, alunos, sindicatos, RH e demais autoridades competentes que um estudo estabeleceria.

Essa comissão ficaria encarregada em promover campanhas de divulgação com o objetivo de sensibilizar todos os servidores, partindo de uma abordagem multidisciplinar, envolvendo médicos, psicólogos, administradores, assistentes sociais, sindicalistas e outros representantes dentro da Instituição UnB. As campanhas teriam como objetivo o esclarecimento sobre o que é assédio moral e os danos gerais por ele causado.

As campanhas sobre esse tema assédio moral compreenderiam diversos tipos de iniciativas e ações, especialmente fazendo uso de formas de divulgação já existentes: slogans; confecções de cartazes, folhetos, banners, cartilhas e outdoors; promoção de fóruns e seminários; publicações em jornais e revistas; participação em programas de rádio e televisão; disseminação pela web, com blogs, emails, twitters e outras formas de interação, divulgação e disseminação que venham ser possíveis.

Todos esses requisitos são fundamentais para uma relação saudável no convívio do trabalho. Jamais deve haver o silêncio! Jamais deve haver omissão!

É certo que o assédio moral jamais será totalmente erradicado do ambiente de trabalho, porém pode-se amenizar seus efeitos, criando medidas de vigilância ativa em prol de relacionamentos mais harmoniosos e humanos, para que todos tenham prazer em trabalhar sem medo, sem angústias e sem terror.

"Se o homem é fruto das estruturas, humanizemos as estruturas", (Karl Marx). 


\section{REFERÊNCIAS}

AGUIAR André Luiz Souza. Assédio Moral: o direito a indenização pelos maus tratos e humilhações. 2. ed. São Paulo: LTR, 2006. 144 pg.

ASSOCIAÇÃO BRASILEIRA DE NORMAS TÉCNICAS. NBR 14724: informação e documentação: trabalhos acadêmicos: apresentação. Rio de Janeiro, 2002 a.

. NBR 10520: Informação e documentação: apresentação de citações em documentos.

Rio de Janeiro, 2002b.

NBR 6023: informação e documentação: referências: elaboração. Rio de Janeiro, 2002c.

BARRETO, Margarida Maria Silveira. Violência, saúde, trabalho: uma jornada de humilhações. 2. ed. São Paulo: PUC, 2000. 233 pg.

- Violência, Saúde e Trabalho: uma jornada de humilhações. 2a reimpr. São Paulo: EDUC, 2006.

BRASIL. Lei n. 8.112, de 11 de dezembro de 1990. Estatuto dos Servidores Públicos Civis da União.

BRASILIANO, Cristina Ribeiro. Assédio moral no trabalho: liame para doenças profissionais. Revista do Ministério Público do Trabalho, n.1. Brasília: LTr, 2005.

FERNANDES, Francisco; LUFT, Celso Pedro; GUIMARÃES, F. Marques (org.). Dicionário Brasileiro Globo. Rio de Janeiro: Globo, 1993.

FERREIRA, D. S. Assédio moral: relações desumanas nas organizações. Rio de Janeiro: Editora Exato, 2006.

FREITAS, M.E., HELOANI, R., BARRETO, M. Assédio moral no trabalho. São Paulo: Cengage Learning, 2008, Coleção Debates em Administração.

GOLDENBERG, M. A arte de pesquisar: como fazer pesquisa qualitativa em Ciências Sociais. 4. ed. Rio de Janeiro: Record, 2000.

GUEDES Márcia Novaes. Terror psicológico no Trabalho. 3. ed. São Paulo: LTR, 2006. 176 pg.

HELOANI Roberto. Gestão e organização no capitalismo globalizado. História da manipulação psicológica no mundo do trabalho. São Paulo: Atlas, 2003. 240 pg. 
HIRIGOYE, Marie-France. Assédio moral: a violência perversa no cotidiano. Rio de Janeiro: Bertrand Brasil, 2002. Título original: Harcèlement Moral: la violence perverse au quotidien, Editora Bertrand.

HIRIGOYE, Marie-France. Mal-estar no trabalho: redefinindo o assédio moral. Tradução de Rejane Janowitzer. Rio de Janeiro: Bertrand Brasil, 2002.

HOUAISS Antônio. Houaiss eletrônico. Versão monousuário 3.0 - Junho de 2009. Instituto Antônio Houaiss. Rio de Janeiro: Objetiva, 2009.

LEYMANN, H. Mobbing and psychological terror at workplaces. Violence and Victims, New York, 5, 2, p. 119-126, 1990.

MASLACH, C. Stress, burnout, and workaholism. In KILBURG R., NATHAN P. E. \& THORESON R. W. (Orgs.), Professionals in distress: Issues, syndromes, and solutions in psychology (pp. 53-75). Washington: American Psychological Association, 1994.

MENEZES, Cláudio Armando Couce de. Assédio moral e seus efeitos jurídicos. ADV: Advocacia Dinâmica. Informativo, São Paulo, v. 23, n. 28, p. 415-410, 2003.

PAZZINATO, Alceu Luiz; SENISE, Maria Helena Valente. História moderna e contemporânea. São Paulo: Editora Ática. 1994.

ROSA, Ana M. de O. Assédio moral: comprometendo a convivência harmônica nas organizações. Disponível em http://www.castroalves/eventos/menuassédio Acessado em 25 de maio de 2010.

SALOMON, D. V. Como fazer uma monografia. 4. ed. São Paulo: Martins Fontes, 1999.

SCHMIDT, M. H. F. de M. O assédio moral no direito do trabalho. Revista do Tribunal Regional do Trabalho da $9^{a}$ Região, Serviço de Biblioteca e Jurisprudência, Curitiba, a. 27, n. 47, jan./jun. 2002, p. 177-227.

SILVA, Jorge Luiz de Oliveira da. Assédio moral no ambiente de trabalho. Rio de Janeiro: Editora e livraria jurídica do Rio de Janeiro, 2005.

TRIVIÑOS, A. N. S. Introdução à pesquisa em ciências sociais: a pesquisa qualitativa em educação. São Paulo: Atlas, 1987.

ZIMMERMMANN, Silvia Maria; SANTOS, Teresa Cristina Dunka Rodrigues dos e LIMA, Wilma Coral Mendes de. O assédio moral no mundo do trabalho. Revista do Ministério Público do Trabalho, n. 1. Brasília: LTr, 2003. 


\section{SITES CONSULTADOS}

http://assediomoral.org/spip.php?article1> O que é assédio moral? Acessado em 23 de maio de 2010.

http://www.assediomoral.org/spip.php?rubrique20.> Acessada em 23 de maio de 2010.

http://cadir-unb.org - História da UnB. Acessado em 17 de maio de 2010.

http://pt.wikipedia.org/wiki/Ass\%C3\%A9dio_moral Assédio Moral. Acessado em: 20 de maio de 2010.

http://pt.wikipedia.org/wiki/Bullying Acessado em: 22 de maio de 2010.

http://wapedia.mobi/pt/Ass\%C3\%A9dio_moral > Acessado em 15 de junho de 2010.

http://www.assediomoral.org - em 11/03/2010.

http://www.assediomoral.org/spip.php?article186 Acessado em 22 de maio de 2010.

http://www.jusbrasil.com.br/noticias/1993725/projeto-combate-assedio-moral-a-servidorpublico http://www.methodus.com.br Acessado em 17 de maio de 2010.

http://www.psicologia.org.br/internacional/pscl87.htm Jorge Luiz de Oliveira da Silva, Assédio Moral no Ambiente de Trabalho. Acessado em: 26 de maio de 2010.

http://www.suapesquisa.com/historiadobrasil/escravidao.htm Acessado em 17 de maio de 2010.

http://www.unifran.br/mestrado/promocaoSaude/docs/ConstituicaodaWHO1946.pdf> Acessado em 17 de maio de 2010.

http://www.webartigos.com - A evolução da mulher no mercado de trabalho Acessado em 17 de maio de 2010 .

www.estagioresponsavel.org.br Acessado em 17 de maio de 2010.

www.oitbrasil.org.br Acessado em 17 de maio de 2010.

< http://www.cesumar.br/epcc2009/anais/rafaela_caroline_schon.pdf> Acessado em 17 de maio de 2010. 


\section{Apêndice A - Questionário aplicado na pesquisa}

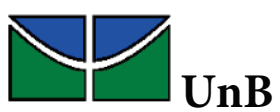

Faculdade de Economia, Contabilidade e Ciência da Informação e Documentação - FACE

Curso: Especialização em Gestão Universitária - Trabalho de Conclusão de Curso (monografia)

Assédio moral: consequências na saúde física e psicológica do servidor da UnB

\section{Questionário}

O objetivo desta pesquisa é identificar a existência de assédio moral e quais as consequências na saúde física e psicológica do servidor da UnB.

Todos os dados aqui fornecidos serão utilizados apenas para fins estatísticos, sendo as suas respostas completamente sigilosas.

Assédio moral significa toda e qualquer conduta abusiva manifestando-se, sobretudo por comportamentos, palavras, atos, gestos, escritos, que possam trazer dano à personalidade, à dignidade ou à integridade física ou psíquica de uma pessoa, pondo em perigo seu emprego ou degradando o ambiente de trabalho. Marie France Hirigoyen, (1998)

\section{Lendo a definição acima:}

1 - Você diria que já foi ou é vítima de assédio moral? SIM ( ) NÃO ( )

Caso afirmativo, em que época ocorreu? a mais ou menos 7 anos atrás

2 - Ainda, se você respondeu SIM, qual o sexo do agressor? Homem ( ) Mulher （ ）

3 - Qual a sua relação de trabalho com o agressor? $\quad$ Chefe $($ ） Subordinado ( ) Colega ( )

4 - Você sofreu ou sofre algum prejuízo em decorrência do assédio moral? SIM （） NÃO ( )

Físico ( ) Psicológico ( ) Financeiro ( ) Justiça ( )

5 - Você é portador de alguma doença? SIM ( ) NÃO ( )

Se afirmativa a resposta acima, você foi ou é discriminado por causa dessa doença? SIM ( ) NÃO ( )

6 - Você conhece na UnB alguma forma de divulgação sobre o que é assédio moral? SIM ( ) NÃO ( )

7 - Qual o seu vínculo com a UnB? Professor （） Aluno（） Técnico administrativo( x )Outro（） Se outro, qual? Técnico de laboratório

8 - Qual a sua escolaridade? Básica ( ) fundamental ( ) superior ( ) outro ( )

Qual?

9 - A que gênero você pertence? Masculino ( ) feminino ( )

10 - Qual a sua faixa etária? - 20 a 30( ) 31 a 41( ) 42 a $52($ ) $\quad 53$ a 63 ( ) Mais ( ) 
Após ter respondido as perguntas e se você se considera que foi ou está sendo assediado moralmente, conte aqui a sua história. Não precisa usar o seu nome. As informações serão usadas exclusivamente para essa pesquisa.

\section{Exemplo}

Lúcia, funcionária pública:

Já sofri assédio moral e não denunciei. O constrangimento não partia de nma só pessoa, mas de todas as que não eram terceirizadas no men setor. A escolaridade dos funcio. nários não importava para a depreciação dos mesmos. Comecei a desenvolver várias doenças $e$, por diversas vezes, fui parar na enfermaria, sendo medicada e dispensada. Jsso gerava conver. sinhas desagradáveis no dia posterior.

Chegaram a duvidar de men estado clínico, e tudo era motivo de piadas. Por fim, não suportava mais conviver naquele ambiente e estava disposta a pedir as contas. Da última vez que passei mal, a médica que me atenden falon que procuraria a chefia, pois $80 \%$ dos fun. cionários daquele departamento apresentavam problemas de saúde por assédio moral.

Saí de lá, graças a Deust- Hoje eston feliz e trabalhando em nm ambiente agradável.

Escreva aqui em poucas linhas a sua história: não precisa colocar o seu nome verdadeiro. 
Curso de Especialização em Gestão Universitária - monografia - Aluna: Ivanise Oliveira de Brito - Orientadora: Professora Dra. Marisa Cardoso Trindade | 1

Universidade de Brasília - UnB

Faculdade de Economia, Contabilidade e Ciência da Informação e Documentação - FACE

Curso: Especialização em Gestão Universitária

Trabalho de Conclusão de Curso (monografia)

Assédio moral: consequências na saúde física e psicológica do servidor da Universidade de Brasília

TABULAÇÃO DAS RESPOSTAS DO QUESTIONÁRIO APRESENTADO A 30 PESSOAS

CODIFICACุÃO DAS RESPOSTAS

Assédio moral significa toda e qualquer conduta abusiva manifestando-se, sobretudo por comportamentos, palavras, atos, gestos, escritos, que possam trazer dano à personalidade, à dignidade ou à integridade física ou psíquica de uma pessoa, pondo em perigo seu emprego ou degradando o ambiente de trabalho. Marie France Hirigoyen, (1998)

Lendo a definição acima:

1 - Você diria que já foi ou é vítima de assédio moral? $\quad 1.1 \mathrm{SIM}($ ) $\quad 1.2 \mathrm{NÃO}($ )

1.3 Caso afirmativo, em que época ocorreu?

2 - Ainda, se você respondeu SIM, qual o sexo do agressor? 2.1 Homem（ ） 2.2 Mulher ( )

3 - Qual a sua relação de trabalho com o agressor? $\quad 3.1$ Chefe ( ) 3.2 Subordinado ( ) 3.3 Colega ( )

4 - Você sofreu ou sofre algum prejuízo em decorrência do assédio moral?4.1 $\operatorname{SIM}(\quad$ ) $4.2 \mathrm{NÃO}($ )

4.3 Físico ( ) 4.4 Psicológico( ) 4.5 Financeiro ( ) 4.6 Justiça ( )

5 - Você é portador de alguma doença? $5.1 \operatorname{SIM}($ ) $\quad 5.2 \mathrm{NÃO}$ （） Se afirmativa a resposta acima, você foi ou é discriminado por causa dessa doença? $5.3 \operatorname{SIM}(\quad) 5.4 \mathrm{NÃO}(\quad)$

6 - Você conhece na UnB alguma forma de divulgação sobre o que é assédio moral?

$6.1 \operatorname{SIM}($ ) $6.2 \mathrm{NÃO}($ )

7 - Qual o seu vínculo com a UnB? 7.1 Professor（） 7.2 Aluno（） $\quad 7.3$ Técnico administrativo( $) 7.4$ Outro (

) 7.5 Se outro, qual? -

8 - Qual a sua escolaridade? 8.1 Básica ( ) 8.2 fundamental ( ) 8.3 superior ( ) 8.4 outro ( )

8.5 Qual? -

9 - A que gênero você pertence? 9.1 Masculino ( ) $\quad 9.2$ feminino ( )

10 - Qual a sua faixa etária? $10.1-20$ a $30($ ) $10.2-31$ a $41($ ) $10.3-42$ a $52($ ) $10.4-53$ a 63 ( ) 10.5 - Mais ( )

Após ter respondido as perguntas e se você se considera que foi ou está sendo assediado moralmente, conte aqui a sua história. Não precisa usar o seu nome. As informações serão usadas exclusivamente para essa pesquisa.

$11-11.1$ Relatou ( ) 


\section{Apêndice C - Tabulação das respostas}

\begin{tabular}{|c|c|c|c|c|c|c|c|c|c|c|c|c|c|c|c|c|c|c|c|c|c|c|c|c|c|c|c|c|c|c|c|c|c|c|c|c|c|c|}
\hline \multirow{3}{*}{ Q } & \multicolumn{36}{|c|}{ PLANILHA DE TABULAÇÃO E CÁLCULO DAS FREQUÊNCIAS } & \multirow{3}{*}{$\begin{array}{l}\text { FREQUENCIA } \\
\text { ABSOLUTA }\end{array}$} & \multirow{3}{*}{$\begin{array}{l}\text { FREOUENCIA } \\
\text { RELATIVA }\end{array}$} \\
\hline & 1 & 2 & 3 & 4 & 5 & 6 & 7 & 8 & 9 & 10 & 111 & 12 & 13 & 14 & 15 & 16 & 17 & 18 & 19 & & 21 & 22 & 23 & 24 & 25 & 26 & 27 & 282 & & 303 & 313 & 32 & 33 & 343 & 35 & 36 & & \\
\hline & & & & & & & & & & & & & & & & & & & & & & & & & & & & & & & & & & & & & & \\
\hline 1 & $\mathrm{x}$ & $x$ & $\mathrm{x}$ & $x$ & $x$ & $x$ & $\mathrm{x}$ & $\mathrm{x}$ & $x$ & $\mathrm{x}$ & $x$ & $\mathrm{x}$ & $x$ & $x$ & $\mathrm{x}$ & $x$ & $x$ & $\mathrm{x}$ & $x$ & $x$ & $\mathrm{x}$ & $x$ & $\mathrm{x}$ & $x$ & $x$ & $\mathrm{x}$ & $x$ & $x$ & $\mathrm{x}$ & $\mathrm{x}$ & $x$ & $x$ & $x$ & $\mathrm{x}$ & $x$ & $x$ & 36 & $100,00 \%$ \\
\hline 1.1 & $x$ & $x$ & $\mathrm{x}$ & $x$ & $x$ & $x$ & $\mathrm{x}$ & & $x$ & $x$ & & $\mathrm{x}$ & $x$ & $x$ & $\mathrm{x}$ & $x$ & $\mathrm{x}$ & $\mathrm{x}$ & & $x$ & $\mathrm{x}$ & & $x$ & & $x$ & $\mathrm{x}$ & & $x$ & & $x$ & & & $x$ & $x$ & & $\mathrm{x}$ & 26 & $72,22 \%$ \\
\hline 1.2 & & & & & & & & $\mathrm{x}$ & & & $\mathrm{x}$ & & & & & & & & $x$ & & & $\mathrm{x}$ & & $x$ & & & $x$ & & $\mathrm{x}$ & & $x$ & $x$ & & & $x$ & & 10 & $27,78 \%$ \\
\hline 1.3 & 2008 & & pp & & 2008 & 1996 & & & 2008 & & & & & & & & & & & & & & 2005 & & 200719 & 90-1993 & & 2009 & & 2008 & & & & & & 2008 & 11 & $30,56 \%$ \\
\hline 2 & $\mathrm{x}$ & $x$ & & $x$ & $x$ & $x$ & $\mathrm{x}$ & & $x$ & $\mathrm{x}$ & & $\mathrm{x}$ & $x$ & $\mathrm{x}$ & $\mathrm{x}$ & $\mathrm{x}$ & $x$ & $x$ & & & $\mathrm{x}$ & & $x$ & & $x$ & $x$ & & $\mathrm{x}$ & & $x$ & & & $x$ & $x$ & & $x$ & 24 & $66,67 \%$ \\
\hline 2.1 & $\mathrm{x}$ & $x$ & & $x$ & & $x$ & $\mathrm{x}$ & & & $\mathrm{x}$ & & $\mathrm{x}$ & $x$ & & $\mathrm{x}$ & & $x$ & & & & & & $x$ & & & & & $x$ & & $\mathrm{x}$ & & & & $\mathrm{x}$ & & $x$ & 15 & $41,67 \%$ \\
\hline 2.2 & & & & & $x$ & & & & $x$ & & & & & $x$ & & $x$ & & $\mathrm{x}$ & & & $x$ & & & & $\mathrm{x}$ & $\mathrm{x}$ & & & & & & & $x$ & & & & 9 & $25,00 \%$ \\
\hline 3. & $x$ & $x$ & $\mathrm{x}$ & $x$ & $x$ & $x$ & $x$ & & $x$ & $x$ & & $x$ & $x$ & $x$ & $x$ & $x$ & $x$ & $x$ & & $x$ & $x$ & & $x$ & & $x$ & $\mathrm{x}$ & & $x$ & & $x$ & & & $x$ & $x$ & & $\mathrm{x}$ & 26 & $72,22 \%$ \\
\hline 3.1 & $x$ & & $x$ & $x$ & & & $\mathrm{x}$ & & $x$ & & & & & & & & $x$ & & & $x$ & & & $\mathrm{x}$ & & $x$ & & & $x$ & & $x$ & & & $x$ & & & $x$ & 13 & $36,11 \%$ \\
\hline 3.2 & & & & & $x$ & & & & & $x$ & & $x$ & $x$ & $x$ & $x$ & & & $x$ & & $x$ & $x$ & & & & & $x$ & & & & & & & & & & & 10 & $27,78 \%$ \\
\hline 3.3 & & $x$ & & & $x$ & $x$ & & & & & & & & & & $x$ & & & & $x$ & x & & & & & & & & & & & & & $x$ & & $x$ & 8 & $22,22 \%$ \\
\hline 4 & $x$ & $x$ & $x$ & $x$ & $x$ & $x$ & $x$ & $x$ & $x$ & $x$ & & $x$ & $x$ & $x$ & $x$ & $x$ & $x$ & $x$ & & $x$ & $x$ & & $x$ & & $x$ & $\mathrm{x}$ & & $x$ & & $x$ & $x$ & & $x$ & $x$ & & $\mathrm{x}$ & 28 & $77,78 \%$ \\
\hline 4.1 & $x$ & $x$ & $\mathrm{x}$ & $x$ & $x$ & $x$ & $x$ & & $x$ & & & x & $x$ & $x$ & $\mathrm{x}$ & $x$ & $x$ & $x$ & & $x$ & x & & $x$ & & & & & $x$ & & $x$ & & & & $x$ & & $x$ & 22 & $61,11 \%$ \\
\hline 4.2 & & & & & & & & $\mathrm{x}$ & & $x$ & & & & & & & & & & & & & & & $\mathrm{x}$ & $\mathrm{x}$ & & & & & $x$ & $x$ & $x$ & & & & 7 & $19,44 \%$ \\
\hline 4.3 & & & & & & & & & & & & $x$ & $x$ & & & $x$ & $x$ & & & & & & $x$ & & & & & & & & 0 & & & & & & 5 & $13,89 \%$ \\
\hline 4.4 & $x$ & & $x$ & $x$ & $x$ & $x$ & $x$ & & $x$ & & & $x$ & $x$ & $x$ & $\mathrm{x}$ & $x$ & $x$ & $\mathrm{x}$ & & & $x$ & & $x$ & & & & & $x$ & & $x$ & & & & & & $x$ & 19 & $52,78 \%$ \\
\hline 4.5 & & & & & & & & & & & & x & $x$ & & & & $x$ & & & & & & $x$ & & & & & 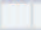 & & 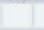 & . & 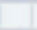 & & & & & 4 & $11,11 \%$ \\
\hline 4.6 & & $x$ & & & & & & & & & & & $x$ & & & & & & & $x$ & & & $x$ & & & & & & & & & & & $x$ & & & 5 & $13,89 \%$ \\
\hline 5 & $x$ & $x$ & $x$ & $x$ & $x$ & $x$ & $x$ & $x$ & $x$ & $x$ & $x$ & $\mathrm{x}$ & $x$ & $x$ & $\mathrm{x}$ & $x$ & $x$ & $x$ & $x$ & $x$ & $x$ & $x$ & $x$ & $x$ & $x$ & $x$ & & $x$ & $x$ & $x$ & $x$ & $x$ & $x$ & $x$ & $x$ & $x$ & 35 & $97,22 \%$ \\
\hline 5.1 & & & & & & $x$ & & & & & & $x$ & & & & & & & & & & & $x$ & & & & & & & & $x$ & $x$ & $x$ & & & & 6 & $16,67 \%$ \\
\hline 5.2 & $x$ & $x$ & $x$ & $x$ & $x$ & & $x$ & $\mathrm{x}$ & $x$ & $x$ & $x$ & & $x$ & $x$ & $\mathrm{x}$ & $x$ & $x$ & $x$ & $x$ & $x$ & $x$ & $x$ & & $x$ & $x$ & $x$ & & $x$ & $x$ & $x$ & & & & $x$ & $x$ & $x$ & 29 & $80,56 \%$ \\
\hline 5.3 & & & & & & $x$ & & & & & & $x$ & & & & & & & & & & & & & & & & & & & & & & & & & 2 & $5,56 \%$ \\
\hline 5.4 & & & & & & & & & & & & & & & & $x$ & & & & & & & & & & $x$ & & & & & $x$ & & $x$ & & & & 4 & $11,11 \%$ \\
\hline 6 & $x$ & $x$ & $x$ & $x$ & $x$ & & $x$ & $x$ & $x$ & $x$ & $x$ & $x$ & $x$ & $x$ & $x$ & $\hat{x}$ & $x$ & $x$ & $x$ & $x$ & $x$ & $x$ & $x$ & $x$ & $x$ & $x$ & & $x$ & $x$ & $x$ & $x$ & $x$ & $\hat{x}$ & $x$ & $x$ & $x$ & 34 & $94,44 \%$ \\
\hline 6.1 & & & & & $x$ & & $x$ & & & $\mathrm{x}$ & & $x$ & $x$ & & & & & & & $\mathrm{x}$ & $x$ & & $x$ & $x$ & & $x$ & & & & $\mathrm{x}$ & $x$ & $x$ & & & & & 13 & $36,11 \%$ \\
\hline 6.2 & $x$ & $x$ & $x$ & $x$ & & & & $x$ & $x$ & & $x$ & & & $x$ & $\mathrm{x}$ & $x$ & $x$ & $x$ & $x$ & & & $x$ & & & $x$ & & & $x$ & $x$ & & & & $x$ & $x$ & $x$ & $x$ & 21 & $58,33 \%$ \\
\hline 7 & $x$ & $x$ & x & & $x$ & $x$ & $x$ & $\mathrm{x}$ & $x$ & $x$ & $x$ & $\mathrm{x}$ & $x$ & $x$ & $\mathrm{x}$ & $x$ & $x$ & $x$ & $x$ & $x$ & $x$ & $x$ & $x$ & $x$ & $x$ & $x$ & $x$ & & $\mathrm{x}$ & $x$ & $x$ & $x$ & $x$ & $x$ & $x$ & $x$ & 34 & $94,44 \%$ \\
\hline 7.1 & & & & & $x$ & & & & & & & & & & & $x$ & & & & $x$ & $x$ & & & & & & & & & & 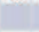 & 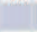 & & 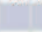 & & & 4 & $11,11 \%$ \\
\hline 7.2 & & & & & & & & & & & & & & & & & & & & & & & & & & & & & & & & & & & & & & $0,00 \%$ \\
\hline 7.3 & $x$ & & x & & & $x$ & & & $x$ & $x$ & $x$ & $x$ & $x$ & $x$ & & & $x$ & $\mathrm{x}$ & & & & $x$ & $x$ & $x$ & $x$ & $x$ & $x$ & & $\mathrm{x}$ & $x$ & $x$ & $x$ & $x$ & & & $\mathrm{x}$ & 23 & $63,89 \%$ \\
\hline 7.4 & & $x$ & & & & & $x$ & $x$ & & & & & & & $x$ & & & & $x$ & & & & & & & & & & 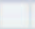 & & & 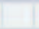 & & $x$ & $x$ & & 7 & $19,44 \%$ \\
\hline 7.5 & & PS & & & & & $\mathrm{TL}$ & PS & & & & & & & PS & & & & PS & & & & & & & & & & & & & & & & PS & & 6 & $16,67 \%$ \\
\hline 8 & $x$ & $x$ & $\mathrm{x}$ & & $x$ & & $x$ & $\mathrm{x}$ & $x$ & $\mathrm{x}$ & $x$ & $x$ & $x$ & $x$ & $x$ & $x$ & $x$ & $x$ & $x$ & $x$ & $x$ & $x$ & $x$ & $x$ & $x$ & $\mathrm{x}$ & $x$ & $x$ & $\mathrm{x}$ & $x$ & $x$ & $x$ & $x$ & $x$ & $x$ & $\mathrm{x}$ & 34 & $94,44 \%$ \\
\hline 8.1 & & & & & & & & & & & & & & & & & & & & & & & & & & & & & & & & & & & & & & $0,00 \%$ \\
\hline 8.2 & & & & & & & & & & & & & & & & & & & & & & & $x$ & & $x$ & & & & & & & & & & & & 2 & $5,56 \%$ \\
\hline 8.3 & $x$ & $x$ & $x$ & & & & $x$ & $x$ & $x$ & $x$ & $x$ & & & $x$ & $x$ & $x$ & $x$ & $x$ & $x$ & $x$ & & & & $x$ & & $x$ & $x$ & $x$ & $x$ & $x$ & $x$ & $x$ & $x$ & $x$ & $x$ & $x$ & 27 & $75,00 \%$ \\
\hline 8.4 & & & & & $x$ & & & & & & & $x$ & $x$ & & & & & & & & $x$ & $x$ & & & & & & & & & & & & & & & 5 & $13,89 \%$ \\
\hline 8.5 & & & EP & & $\widehat{D R}$ & & & & & ES & & ES & $\hat{p l}$ & & & & & & & & $\widehat{D R}$ & $\hat{P G}$ & & & & PG & & & & & & & & & & & 8 & $22,22 \%$ \\
\hline 9 & $\mathrm{x}$ & $x$ & $x$ & $x$ & $x$ & $x$ & $x$ & $\mathrm{x}$ & $x$ & $\mathrm{x}$ & $x$ & $x$ & $x$ & $x$ & $x$ & $x$ & $x$ & $x$ & $x$ & $x$ & $x$ & $x$ & $x$ & $x$ & $x$ & $x$ & $x$ & $x$ & $x$ & $x$ & $x$ & $x$ & $x$ & $x$ & $x$ & $x$ & 36 & $100,00 \%$ \\
\hline 9.1 & & & $x$ & & & & & $x$ & $x$ & & $x$ & & $x$ & $x$ & & & & & & & $x$ & & $x$ & & & & & & & & $x$ & $x$ & $x$ & $x$ & $x$ & & 13 & $36,11 \%$ \\
\hline 9.2 & $x$ & $x$ & & $x$ & $x$ & $x$ & $x$ & & & $x$ & & $x$ & & & $x$ & $x$ & $x$ & $\mathrm{x}$ & $x$ & $x$ & & $x$ & & $x$ & $x$ & $x$ & $x$ & $x$ & $\mathrm{x}$ & $x$ & & & & & & $\mathrm{x}$ & 23 & $63,89 \%$ \\
\hline 10 & $\mathrm{x}$ & & $x$ & $x$ & $x$ & $x$ & $x$ & $x$ & $x$ & $x$ & $x$ & $x$ & $x$ & $x$ & $x$ & $x$ & $x$ & $x$ & $x$ & $x$ & $x$ & $x$ & $x$ & $x$ & $x$ & $x$ & $x$ & $x$ & $x$ & & $x$ & $x$ & $x$ & $x$ & $x$ & $x$ & 34 & $94,44 \%$ \\
\hline 10.1 & & & & & & & & & $x$ & & & & & & & & & & & & & & & $x$ & & & $x$ & & & & & & & & & & 3 & $8,33 \%$ \\
\hline 10.2 & & & $x$ & & & & & & & & $x$ & & & & & & & & & & $x$ & & & & & & & $x$ & $x$ & & & & & & $x$ & & 6 & $16,67 \%$ \\
\hline 10.3 & $x$ & & & $x$ & $x$ & $x$ & $x$ & $x$ & & $x$ & & $x$ & $x$ & $x$ & & $x$ & $x$ & $x$ & $x$ & & & & $x$ & & $x$ & $x$ & & & & & & & $x$ & $x$ & & $x$ & 20 & $55,56 \%$ \\
\hline 10.4 & & & & & & & & & & & & & & & $x$ & & & & & & & $x$ & & & & & & & & & $x$ & $x$ & & & & & 4 & $11,11 \%$ \\
\hline 10.5 & & & & & & & & & & & & & & & & & & & & $x$ & & & & & & & & & & & & & & & & & 1 & $2,78 \%$ \\
\hline 11 & $x$ & & $x$ & $x$ & $x$ & $x$ & $x$ & & & $x$ & & $x$ & $x$ & $x$ & $x$ & $x$ & $x$ & $x$ & & & $x$ & & $x$ & & & $x$ & & & & & & & $x$ & & & $x$ & 19 & $52,78 \%$ \\
\hline 11.1 & $x$ & & $x$ & $x$ & $x$ & $x$ & $x$ & & & $x$ & & $x$ & $x$ & $x$ & $x$ & $x$ & $x$ & $x$ & & & $x$ & & $x$ & & & $x$ & & & & & & & $x$ & & & $\hat{x}$ & 19 & $52,78 \%$ \\
\hline
\end{tabular}


Leis específicas:

"Art. 121. Matar alguém [...]" Apesar de parecer exagerada a assertiva, mas se a vítima sofre de doenças cardíacas (ou outra qualquer que solicita cuidados especiais) e psicológicas, sendo, abusivamente, colocada em situação que venha agravar seu estado, levando-a a óbito, fica o assediador, se devidamente comprovado seu conhecimento do perigo, responsável pela morte.

"Art. 122 - Induzir ou instigar alguém a suicidar-se [...]". Se a conduta abusiva agravar a situação psicológica da vítima, sabendo e querendo isso o assediador, levando a vítima a cometer esse ato extremo, deverá ele ser responsabilizado.

“Art. 129. Ofender a integridade corporal ou a saúde de outrem [...]". É a chamada lesão corporal. Observa-se que a saúde não é só a física, mas, também, a psicológica. Por isso, condutas abusivas, na forma de assédio moral, podem causar lesões tanto físicas quanto psicológicas à vítima e, nesse caso, havendo provas suficientes da casualidade, devese processar penalmente o agressor.

"Art. 138 - Caluniar alguém, imputando-lhe falsamente fato definido como crime [...]; Art. 139 - Difamar alguém, imputando-lhe fato ofensivo à sua reputação [...]; Art. 140 - Injuriar alguém, ofendendo-lhe a dignidade ou o decoro [...]”. São os chamados crimes contra a honra. Veja-se que todos estão solidamente fundados na violação dos direitos constitucionais protegidos pelos arts. $1^{\circ}$. nos seus incisos III e IV, combinados com o art. $5^{\circ}$., caput, e seus incisos V e X da CF/1988, cf. já vistos. Logo, a despeito do processo civil, deve-se processar penalmente o agressor, pois é crime.

"Art. 146 - Constranger alguém, mediante violência ou grave ameaça, ou depois de lhe haver reduzido, por qualquer outro meio, a capacidade de resistência, a não fazer o que a lei permite, ou a fazer o que ela não manda [...]". Este e o artigo a seguir são os principais artigos do $\mathrm{CPB}$ que apóiam uma ação penal contra o assediador autoritário ou chantagista. Invariavelmente, toda conduta abusiva de superior está enquadrada nesses artigos. Esse assunto fica mais completo com o artigo seguinte. 
"Art. 147 - Ameaçar alguém, por palavra, escrito ou gesto, ou qualquer outro meio simbólico, de causar-lhe mal injusto e grave [...]”. Conforme comentários no parágrafo anterior, este artigo combinado com o seu precedente, são essenciais para fundamentar a ação penal de assédio moral. A primeira vista, ele é dirigido a todo tipo de ameaça. Mas, no assédio moral, os chantagistas dele se valem para reduzir a vontade da vítima.

“Art. 149. Reduzir alguém a condição análoga à de escravo, quer submetendo-o a trabalhos forçados ou a jornada exaustiva, quer sujeitando-o a condições degradantes de trabalho, quer restringindo, por qualquer meio, sua locomoção em razão de dívida contraída com o empregador ou preposto [...]" Essa é uma das fórmulas usadas por assediadores para impor à vítima trabalhos excessivos e degradantes.

O tipo penal acima é mais aplicado às vítimas de trabalhos em locais afastados e sem possibilidade de facilmente se safar do constrangimento. É, modernamente, também caracterizado por atribuir sobrecarga de serviços à trabalhadores urbanos, violando os termos de contrato de trabalho ou impondo desvios de funções, sob ameaça velada de despedida do emprego ou outro mal que o assediador achar pertinente.

\footnotetext{
“Art. 151 - Devassar indevidamente o conteúdo de correspondência fechada, dirigida a outrem $[. .] \.$ 1^{\circ}$ - Na mesma pena incorre: I - quem se apossa indevidamente de correspondência alheia, embora não fechada e, no todo ou em parte, a sonega ou destrói; II - quem indevidamente divulga, transmite a outrem ou utiliza abusivamente comunicação telegráfica ou radioelétrica dirigida a terceiro, ou conversação telefônica entre outras pessoas; III - quem impede a comunicação ou a conversação referidas no número anterior; [...].
}

Esses são fatos modernamente corriqueiros. As organizações e mesmo as instituições, por meio de condutas abusivas de suas chefias ou empregados/servidores, se julgam no direito de interferir nas correspondências da vítima. Alegam para isso que os meios de comunicação interferidos são de suas propriedades. Esquecem que a guarda desses meios estão com a vítima. O que esses assediadores podem legalmente fazer é pedir de volta o meio de comunicação, mas não invadi-lo. Isso constitui, no mínimo, invasão de privacidade.

“Art. 153 - Divulgar alguém, sem justa causa, conteúdo de documento particular ou de correspondência confidencial, de que é destinatário 

ou detentor, e cuja divulgação possa produzir dano a outrem [...]." Essa é outra conduta usada pelos assediadores. Procuram desacreditar a vítima, divulgando informações que tiveram conhecimento em razão da oportunidade ou do cargo. Devem portanto ser processados penalmente.

“Art. 163 - Destruir, inutilizar ou deteriorar coisa alheia [...] IV - por motivo egoístico ou com prejuízo considerável para a vítima [...]”. Esse crime, crime de dano, é usado como expediente do assediador que quer destruir a imagem ou reputação da vítima. Geralmente é realizado por colegas despeitados ou ciumentos no ambiente de trabalho. Quando surpreendidos executando o ato ilícito, quase sempre alegam que é uma brincadeira. Deve-se denunciá-los imediatamente, inclusive penalmente se o dano já se realizou com prejuízo para a vítima.

Art. 197 - Constranger alguém, mediante violência ou grave ameaça: I - a exercer ou não exercer arte, ofício, profissão ou indústria, ou a trabalhar ou não trabalhar durante certo período ou em determinados dias [...]" Por aqui se vê uma das principais ações dos assediadores, principalmente por aqueles que querem impor greves ou paralisações inapropriadas, constrangendo a vítima a aderir às suas idéias. Ou forçar a vítima legalmente dispensada a trabalhar em seu proveito.

"Art. 199 - Constranger alguém, mediante violência ou grave ameaça, a participar ou deixar de participar de determinado sindicato ou associação profissional [...]".

"Art. 203 - Frustrar, mediante fraude ou violência, direito assegurado pela legislação do trabalho [...].”

“Art. 208 - Escarnecer de alguém publicamente, por motivo de crença ou função religiosa [...]". Muito comum no ambiente de trabalho.

“Art. 214-A - Constranger alguém com o intuito de obter vantagem ou favorecimento sexual, prevalecendo-se o agente da sua condição de superior hierárquico ou ascendência inerentes ao exercício de emprego, cargo ou função.” Aqui está discriminado o assédio sexual. Nada mais é preciso acrescentar.

Independentemente das responsabilidades civis ou penais, há também a responsabilidade administrativa. No caso dos servidores públicos, o Estatuto do Servidores Públicos Civis da União, Lei no ${ }^{\circ} 8.112$ de 11 de dezembro de 1990, no seu art. 104, assegura o 
direito de petição, permitindo ao servidor requerer um processo investigativo no âmbito administrativo, quando sofrer de coação ou sob conduta abusiva.

Para orientação do servidor, esse mesmo Estatuto discrimina nos seus arts. 116 e 117 os direitos e as proibições inerentes a todos servidores.

\section{“Capítulo I - Dos Deveres}

Art. 116. São deveres do servidor:

I - exercer com zelo e dedicação as atribuições do cargo;

II - ser leal às instituições a que servir;

III - observar as normas legais e regulamentares;

IV - cumprir as ordens superiores, exceto quando manifestamente ilegais;

$[\ldots]$;

VI - levar ao conhecimento da autoridade superior as irregularidades de que tiver ciência em razão do cargo;

VIII - guardar sigilo sobre assunto da repartição;

$[\ldots]$

IX - manter conduta compatível com a moralidade administrativa;

$[\ldots]$;

$\mathrm{XI}$ - tratar com urbanidade as pessoas;

XII - representar contra ilegalidade, omissão ou abuso de poder.

Parágrafo único. A representação de que trata o inciso XII será encaminhada pela via hierárquica e apreciada pela autoridade superior àquela contra a qual é formulada, assegurando-se ao representando ampla defesa.

\section{Capítulo II - Das Proibições}

Art. 117. Ao servidor é proibido:

$[\ldots]$;

IV - opor resistência injustificada ao andamento de documento e processo ou execução de serviço;

$\mathrm{V}$ - promover manifestação de apreço ou desapreço no recinto da repartição;

VI - cometer a pessoa estranha à repartição, fora dos casos previstos em lei, o desempenho de atribuição que seja de sua responsabilidade ou de seu subordinado;

VII - coagir ou aliciar subordinados no sentido de filiarem-se a associação profissional ou sindical, ou a partido político;

VIII - manter sob sua chefia imediata, em cargo ou função de confiança, cônjuge, companheiro ou parente até o segundo grau civil; 
IX - valer-se do cargo para lograr proveito pessoal ou de outrem, em detrimento da dignidade da função pública;

$[\ldots]$;

$\mathrm{XV}$ - proceder de forma desidiosa;

XVI - utilizar pessoal ou recursos materiais da repartição em serviços ou atividades particulares;

XVII - cometer a outro servidor atribuições estranhas ao cargo que ocupa, exceto em situações de emergência e transitórias;

XVIII - exercer quaisquer atividades que sejam incompatíveis com o exercício do cargo ou função e com o horário de trabalho; " 